\title{
$\beta$-catenin nuclear translocation induced by HIF-1 $\alpha$ overexpression leads to the radioresistance of prostate cancer
}

\author{
YONG LUO ${ }^{1}$, MINGCHUAN LI ${ }^{1}$, XUEMEI ZUO ${ }^{2}$, SPYRIDON P. BASOURAKOS $^{3}$, JIAO ZHANG $^{4}$, JIAHUI ZHAO $^{1}$, \\ YILI HAN ${ }^{1}$, YUNHUA LIN ${ }^{1}$, YONGXING WANG ${ }^{1}$, YONGGUANG JIANG ${ }^{1}$ and LING LAN ${ }^{5}$ \\ ${ }^{1}$ Department of Urology, Beijing Anzhen Hospital, Capital Medical University, Beijing 100029; \\ ${ }^{2}$ Department of Clinical Laboratory, Tong Ren Hospital, Shanghai JiaoTong University School of Medicine, \\ Shanghai 200233, P.R. China; ${ }^{3}$ Department of Genitourinary Medical Oncology, Cancer Medicine, \\ MD Anderson Cancer Center, The University of Texas, Houston, TX 77030; ${ }^{4}$ Department of Anatomy and Cell Biology, \\ Brody School of Medicine, East Carolina University, Greenville, NC 27834, USA; ${ }^{5}$ Department of Endocrinology, \\ Beijing Jishuitan Hospital, The 4th Medical College of Peking University, Beijing 100035, P.R. China
}

Received May 10, 2017; Accepted March 16, 2018

DOI: 10.3892/ijo.2018.4368

\begin{abstract}
Hypoxia-inducible factor-1 $\alpha$ (HIF-1 $\alpha$ ) is known to play crucial roles in tumor radioresistance; however, the molecular mechanisms responsible for the promotion of tumor radioresistance by HIF- $1 \alpha$ remain unclear. $\beta$-catenin is known to be involved in the metastatic potential of prostate cancer (PCa). In this study, to investigate the role of HIF-1 $\alpha$ and $\beta$-catenin in the radioresistance of $\mathrm{PCa}$, two PCa cell lines, LNCaP and C4-2B, were grouped as follows: Negative control (no treatment), HIF-1 $\alpha$ overexpression group (transfected with HIF-1 $\alpha$ overexpression plasmid) and $\beta$-catenin silenced group (transfected with HIF- $1 \alpha$ plasmids and $\beta$-catenin-shRNA). Cell proliferation, cell cycle, cell invasion and radiosensitivity were examined under normal or hypoxic conditions. In addition, radiosensitivity was examined in two mouse $\mathrm{PCa}$ models (the LNCaP orthotopic BALB/c-nu mice model and the C4-2B subcutaneous SCID mice model). Our results revealed that in
\end{abstract}

Correspondence to: Dr Yong Luo, Department of Urology, Beijing Anzhen Hospital, Capital Medical University, 2 Anzhenli Street, Chaoyang, Beijing 100029, P.R. China

E-mail: luoyonganzhen@163.com

Professor Ling Lan, Department of Endocrinology, Beijing Jishuitan Hospital, The 4th Medical College of Peking University, 31 Xinjiekou East Street, Xicheng, Beijing 100035, P.R. China E-mail: lanjingling0627@163.com

Abbreviations: PCa, prostate cancer; HIF-1 $\alpha$, hypoxia-inducible factor-1 $\alpha$; NHEJ, non-homologous end joining; DSB, DNA doublestrand breaks; RT-qPCR, reverse transcription-quantitative polymerase chain reaction; EGFP1, enhanced green fluorescent protein 1; FITC, fluorescein isothiocyanate; SPF, specific pathogen-free

Key words: prostate cancer, hypoxia-inducible factor- $1 \alpha, \beta$-catenin, cell proliferation, radioresistance both the LNCaP and C4-2B cells, transfection with HIF-1 $\alpha$ overexpression plasmid led to an enhanced $\beta$-catenin nuclear translocation, while $\beta$-catenin silencing inhibited $\beta$-catenin nuclear translocation. The enhanced $\beta$-catenin nuclear translocation induced by HIF-1 $\alpha$ overexpression resulted in an enhanced cell proliferation and cell invasion, an altered cell cycle distribution, decreased apoptosis, and improved non-homologous end joining (NHEJ) repair under normal and irradiation conditions. Similar results were observed in the animal models. HIF-1 $\alpha$ overexpression enhanced $\beta$-catenin nuclear translocation, which led to the activation of the $\beta$-catenin/NHEJ signaling pathway and increased cell proliferation, cell invasion and DNA repair. These results thus suggest that HIF-1 $\alpha$ overexpression promotes the radioresistance of PCa cells.

\section{Introduction}

Globally, prostate cancer (PCa) is the most commonly diagnosed type of cancer in males (1). In 2015, the incidence of PCa in Chinese males was estimated to be 9 per 100,000 individuals and the mortality rate was approximately 4.5 per 100,000 individuals. From 2005 to 2011, the average percentage increase in the incidence of $\mathrm{PCa}$ in China was $4.7 \%$, representing the fastest growth rate in all cancer types in males (2). These data indicate a high disease burden by PCa in China

The majority of cases of PCa are diagnosed at an early stage and treatments include surgery and radiotherapy, with or without androgen deprivation $(1,3,4)$. Depending on the tumor stage, between 55 and $90 \%$ of all PCa cases can be permanently controlled by radiotherapy (4-6). However, approximately $50 \%$ of patients with $\mathrm{PCa}$ receiving radiotherapy will relapse within 5 years of treatment $(7,8)$. Relapse following radiotherapy is multifactorial. It can result from an intrinsic radioresistance of a subpopulation of clones within the tumor (9), or from acquired radioresistance during radiotherapy (10-12). Therefore, radioresistance is a major challenge in the treatment of PCa. 
Oxygen is one of the most influential factors on the cytotoxic effects of radiation, due to its high affinity for free radicals produced by radiation in cellular components. Solid tumors usually have highly abnormal blood vessels and distended capillaries with leaky walls and sluggish flow, indicating a hypoxic environment that reduces the effects of radiation and promotes resistance to radiotherapy in solid tumors $(13,14)$. In addition to the lack of oxygen as a chemical mechanism of resistance to radiation, cellular adaptive responses to hypoxia mediated by hypoxia-inducible factor- $1 \alpha$ (HIF-1 $\alpha$ ) are involved in the induction of radioresistance in cancer cells $(14,15)$. HIF-1 $\alpha$ is activated in cancer cells, not only under hypoxic conditions, but also under normoxic conditions through cancer-specific genetic alterations and the resulting imbalance in intermediate metabolites (16). Indeed, HIF-1 $\alpha$ is activated in the presence of decreased $\mathrm{Fe}^{2+}$ or $\alpha$-ketoglutarate levels (16). HIF-1 $\alpha$ mediates radioresistance through a number of methods: i) By the reprogramming of glucose metabolism and the overproduction of antioxidants; ii) nucleic acid synthesis; iii) cell cycle regulation; iv) the protection of tumor blood vessels; and v) the repopulation of surviving cells after radiotherapy (16). Therefore, HIF-1 $\alpha$ is considered to play crucial roles in tumor radioresistance; however, the molecular mechanisms downstream of HIF-1 $\alpha$ which are responsible for tumor radioresistance remain unclear.

The $\beta$-catenin signaling pathway regulates embryogenesis and tumor progression. Existing studies have demonstrated that the inhibition of $\beta$-catenin can lead to an enhanced radiosensitivity of the PCa cell line, PC3, and of the significantly radioresistant cancer cell line, AMC-HN-9 $(17,18)$. The overexpression of HIF-1 $\alpha$ promotes the invasive potential of human PCa cells through epithelial-mesenchymal transition (EMT) and $\beta$-catenin plays a vital role in this process $(19,20)$. The knockdown of $\beta$-catenin induced by HIF- $1 \alpha$ causes the reversal of EMT and metastatic phenotypic changes (19). This suggests a potential mechanism involving $\beta$-catenin through which HIF-1 $\alpha$ controls radioresistance in PCa.

The present study aimed to investigate the molecular mechanisms in relation to $\beta$-catenin that are downstream of HIF-1 $\alpha$, which may contribute to the radioresistance of prostate tumors. In addition, we utilized both PCa cell lines and animal models to examine our hypothesis through in vitro and in vivo interventions. Furthermore, we investigated protein markers for cell proliferation, cell invasion, cell cycle distribution, cell death and DNA repair in order to provide a comprehensive understanding of biological functional changes under the activation or inhibition of $\beta$-catenin with or without radiation treatment.

\section{Materials and methods}

Cell lines. The human PCa cell lines, $\mathrm{LNCaP}$ and $\mathrm{C} 4-2 \mathrm{~B}$, were generous gifts from Dr Likun Li (MD Anderson Cancer Center). These two cell lines were validated by short tandem repeat DNA fingerprinting with the AmpFLSTR Identifiler kit (Applied Biosystems, Foster City, CA, USA) at the MD Anderson's Characterized Cell Line Core Facility. Both cell lines were cultured in DMEM containing $1 \mathrm{mM}$ sodium pyruvate, $2.5 \mathrm{mM}$ glutamine, $10 \% \mathrm{FBS}, 100 \mathrm{U} / \mathrm{ml}$ penicillin and $100 \mu \mathrm{g} / \mathrm{ml}$ streptomycin at $37^{\circ} \mathrm{C}$ in a humidified incubator containing $5 \% \mathrm{CO}_{2}$. The $\mathrm{LNCaP}$ or $\mathrm{C} 4-2 \mathrm{~B}$ cells were divided into 3 experimental groups as follows: The negative control (no treatment), the HIF-1 $\alpha$ overexpression group [transfected with the PcDNA3.1(-)/HIF-1 $\alpha$ plasmid and screened for HIF-1 $\alpha$ high expression clones] and the $\beta$-catenin silenced group (PSuper$\beta$-catenin-shRNA vector used in HIF-1 $\alpha$-overexpressing cells to inhibit $\beta$-catenin expression and selected for clones with stable silencing of $\beta$-catenin). The negative control and $\beta$-catenin silenced groups were incubated under normoxic conditions (18\% oxygen). Cells in the HIF-1 $\alpha$ overexpression group were cultured under hypoxic conditions (1\% oxygen; Biospherix, Ltd., Parish, NY, USA) during clone selection, and grown under normoxic conditions after the clones were identified and stabilized.

Plasmid transfection and RNA interference. In the HIF-1 $\alpha$ overexpression group, PcDNA3.1(-)/HIF-1 $\alpha$ recombinant plasmid transfection was conducted using Lipofectamine 2000 (Invitrogen Inc., Carlsbad, CA, USA) as described previously (20). During preliminary experiments (data not shown), to further confirm that HIF-1 $\alpha$ overexpression was due to transfection with the PcDNA3.1(-)/HIF-1 $\alpha$ plasmids, a second negative control using PcDNA3.1(-) plasmid transfection was conducted in both cell lines.

A PSuper-enhancement green fluorescent protein 1 (EGFP1) vector was used to construct the PSuper- $\beta$-cateninShRNA and PSuper-Scramble- $\beta$-catenin-ShRNA plasmids based on a previous study (21). The $\beta$-catenin-shRNA and scramble- $\beta$-catenin-shRNA primer sequences are listed below. In the $\beta$-catenin silenced group, HIF-1 $\alpha$ overexpression clones were further knocked down for $\beta$-catenin expression using the $\beta$-catenin-shRNA plasmids using Lipofectamine RNAiMax transfection reagent (Life Technologies Co., Grand Island, NY, USA). During preliminary experiments (data not shown), to further that confirm $\beta$-catenin inhibition in the $\beta$-catenin silenced group was caused by $\beta$-catenin-shRNA transfection, a second negative control using scramble- $\beta$-catenin-ShRNA transfection was conducted in both cell lines. $\beta$-catenin expression was identified in these clones by a fluorescence microscope, reverse transcription-quantitative polymerase chain reaction (RT-qPCR) and western blot analysis. RNA interference was conducted based on a previously published protocol (19).

The primer sequences of the shRNAs were as follows: $\beta$-catenin-shRNA forward, 5'-GAT CCC CGC AAC AGT CTT ACC TGG ACT TCA AGA GAG TCCAGG TAA GAC TGT TGC TTT TTA-3' and reverse, $3^{\prime}$ GGG CGT TGT CAG AAT GGA CCT GAA GTT CTC TCA GGT CCA TTC TGA CAA CGA AAA ATT CGA5'; and scramble- $\beta$-cateninshRNA forward, 5'-GAT CCC CAA CGA GTG TGC CTA CAT CCT TCA AGA GAG GAT GTA GGC ACA CTC GTT TTT TTA-3' and reverse, 3'-GGG TTG CTC ACA CGG ATG TAG GAA GTT CTC TCC TAC ATC CGT GTG AGC AAA AAA ATT CGA-5'.

Immunofluorescence. The cells were fixed in $10 \%$ paraformaldehyde for $30 \mathrm{~min}$ and blocked with goat serum for $30 \mathrm{~min}$. The cells were incubated at $37 \mathrm{oC}$ for $1 \mathrm{~h}$ with mouse anti-human $\beta$-catenin monoclonal antibody (sc7963, Santa Cruz Biotechnology, Santa Cruz, CA, USA) at a dilution of 1:200. After being washed 3 times with PBS, the 
cells were co-incubated with fluorescein isothiocyanate (FITC)-conjugated goat anti-mouse antibody (sc2010, Santa Cruz Biotechnology) at $37^{\circ} \mathrm{C}$ for $1 \mathrm{~h}$. The fluorescence staining intensity and intracellular localization were then determined by a fluorescence microscope (Olympus Corporation, Tokyo, Japan).

Western blot analysis. The cells were harvested after being washed with phosphate-buffered saline (PBS) twice, lysed with RIPA cell lysis buffer (Thermo Fisher Scientific, Waltham, MA, USA) for $30 \mathrm{~min}$ on ice, and centrifuged at $16,000 \mathrm{x} \mathrm{g}$ for $15 \mathrm{~min}$ at $4^{\circ} \mathrm{C}$. The concentration of total protein was determined using a BCA protein assay kit. The clarified protein lysates $(50 \mu \mathrm{g} / \mathrm{load})$ were then separated on denaturing $10 \%$ SDS-PAGE gels and electro-transferred onto nitrocellulose membranes. The membranes were initially incubated with $5 \%$ non-fat dry milk in TBS for $2 \mathrm{~h}$, and then probed at $4{ }^{\circ} \mathrm{C}$ overnight with the following antibodies: anti-HIF-1 $\alpha$ (sc53546, 1:1,000), anti-Glut-1 (sc1605, 1:1,000), anti-VEGF (sc7269, 1:500) (HIF-1 $\alpha$ signaling markers, Santa Cruz Biotechnology), anti-t- $\beta$-catenin (ab16051, 1:1,000), anti-p- $\beta$-catenin (Ser45, ab18824, 1:500), anti-p- $\beta$-catenin (Y654, ab59430, 1:500), anti-t-GSK-3 $\beta$ (ab131356, 1:500), anti-p-GSK-3 $\beta$ (Ser9, ab131097, 1:500) ( $\beta$-catenin signaling markers; Abcam, Cambridge, MA, USA), anti-E-cadherin (sc8426, 1:1,000) and anti-CK18 (sc70917, 1:1,000) (epithelial markers; Santa Cruz Biotechnology), anti-vimentin (sc6260, 1:1,000), anti-fibronectin (sc8422, 1:500), anti-matrix metalloproteinase (MMP)2 (sc13595, 1:500) (mesenchymal markers; Santa Cruz Biotechnology), anti-vascular endothelial growth factor receptor (VEGFR; ab2349, 1:50) (angiogenesis marker; Abcam), anti-CDK1 (ab18, 1:1,000), anti-p-CDK1 (Y15, ab47594, 1:1,000), anti-Chk1 (ab47574, 1:1,000), anti-p-Chk1 (S296, ab79758, 1:500), anti-Chk2 (ab47433, 1:500), anti-p-Chk2 (T387, ab55319, 1:500), anti-Rb (ab226979, 1:1,000), anti-p-Rb (S780, ab173289, 1:100), anti-p21 (ab227443, 1:500) (cell cycle markers; Abcam), anti-caspase-3 (cs9662) (1:1,000), anti-cleaved-caspase-3 (Asp 175, cs9661, 1:1,000), anti-caspase-7(cs9492,1:500), anti-cleaved-caspase-7(Asp 198, cs9491, 1:500), anti-cleaved poly(ADP-ribose) polymerase (PARP)-1 (Asp214, cs5625, 1:500), anti-Bax (cs2772, 1:1,000) (apoptosis markers; Cell Signaling Technology, Danvers, MA, USA), anti-Bcl-2 (cs2872, 1:1,000), and anti-Bcl-xL (cs2762, 1:1,000) (anti-apoptosis markers; Cell Signaling Technology), anti- $\gamma \mathrm{H} 2 \mathrm{AX}$ (cs7631, 1:250) [DNA double-strand break (DSB) marker; Cell Signaling Technology], anti-Ku70 (ab53126, 1:500), anti-Ku80 (ab53126, 1:500) and anti-DNA-dependent protein kinase, catalytic subunit (DNA-PKcs; ab230, 1:500) [non-homologous end joining (NHEJ) pathway markers; Abcam] and anti-GAPDH (sc47724, 1:1,000) (internal control, Santa Cruz Biotechnology) antibodies. The membranes were then hybridized with an appropriate horseradish peroxidase (HRP)-conjugated secondary antibody (sc2004/sc2005, Santa Cruz Biotechnology) for $2 \mathrm{~h}$ at room temperature. An enhanced chemiluminescence system (Amresco Inc., Solon, OH, USA) was used to detect the immunopositive protein bands.

MTT assay. The cells ( $1 \times 10^{4} /$ well) were placed into 96 -well plates. At 24, 48 and $72 \mathrm{~h}, 50 \mu \mathrm{l}$ MTT solution $(2.5 \mathrm{mg} / \mathrm{ml}$; $50 \mu \mathrm{l})$ were added followed by incubation for an additional
4 h. Cell-associated MTT crystals were dissolved in DMSO (150 $\mu \mathrm{l} /$ well). The color intensity was measured at $570 \mathrm{~nm}$ using a microplate reader (Bio-Rad, Hercules, CA, USA).

In vitro invasion assay. Polycarbonate filters (8- $\mu \mathrm{m}$-thick; Millipore corp., Billerica, MA, USA) were coated with $50 \mu \mathrm{g} / \mathrm{cm}^{2}$ of reconstituted Matrigel (Sigma, St. Louis, MO, USA). The cells $(50,000$ in $300 \mu 1$ of serum-free growth medium) were seeded into the upper chamber. The cells were incubated under normoxic conditions and allowed to migrate toward the complete growth medium for 24,48 and $72 \mathrm{~h}$. Non-invading cells were removed mechanically using cotton swabs. The migrated cells, located on the lower surface, were fixed with methanol and stained with Giemsa (G1062, Solarib Biotechnology, Beijing, China). The number of migrating cells was determined by counting 10 random fields of view on each membrane and photographed by field at x400 magnification under an inverted microscope (Olympus Corporation). Data are presented as the mean number of cells per field. Each experiment was repeated 3 times.

Flow cytometry. The cells were harvested and stained with propidium iodide for $30 \mathrm{~min}$ at room temperature. Analysis was performed at a 405-nm excitation and emission collected with a 450/50 band-pass filter using a FACSCanto II Flow Cytometer (BD Biosciences, Franklin Lakes, NJ, USA). Histograms of DNA content were analyzed using FlowJo software (Tree Star Inc, Ashland, OR, USA) to determine cell cycle distribution.

Clonogenic survival assay. The cells were seed in 6-well plates at $2 \times 10^{4} /$ well. After sequential radiation and maintenance, the cells were fixed with $100 \%$ cold methanol for $20 \mathrm{~min}$, washed once with PBS, and stained with $0.5 \%$ crystal violet (G1062, Solarib Biotechnology) diluted in $20 \%$ methanol for $20 \mathrm{~min}$. Colonies were stained with crystal violet and counted with a computer-assisted program as described previously. Colonies with $>50$ cells were counted under a microscope.

DNA fragmentation assay. A DNA fragmentation assay was performed using a Cell Death Detection ELISA kit (Roche, Mannheim, Germany) for the apoptotic evaluation of in vitro radiation to cells with different $\beta$-catenin expression and location, according to previously published methods (22). DNA fragmentation was quantified by measuring absorbance at $405 \mathrm{~nm}$ with a reference wavelength at $490 \mathrm{~nm}$. Data presented are representative of 3 or more independent experiments.

In vitro radiation treatment. The cells were seeded onto proper cell-culture plates $24 \mathrm{~h}$ prior to irradiation. The cells were irradiated at room temperature with a single dose of $6 \mathrm{~Gy}$ at a rate of $1 \mathrm{~Gy} / \mathrm{min}$ using a Gamma cell 40 Exactor (137Cs $\gamma$-ray photon radiation; Nordion, Ottawa, Canada). Following irradiation, all samples were returned to a $5 \% \mathrm{CO}_{2}$ incubator and maintained $72 \mathrm{~h}$ for DNA fragmentation assay, sub-G1 population detection, clonogenic survival assay, flow cytometry and western blot analysis, and 14 days for colony formation assay.

Animals. BALB/c nude mice and SCID mice (male, 4 weeks old, 20-25 g) were purchased from Charles River Laboratories 
A
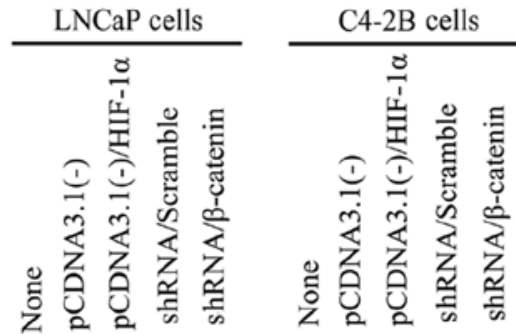

HIF- $1 \alpha$
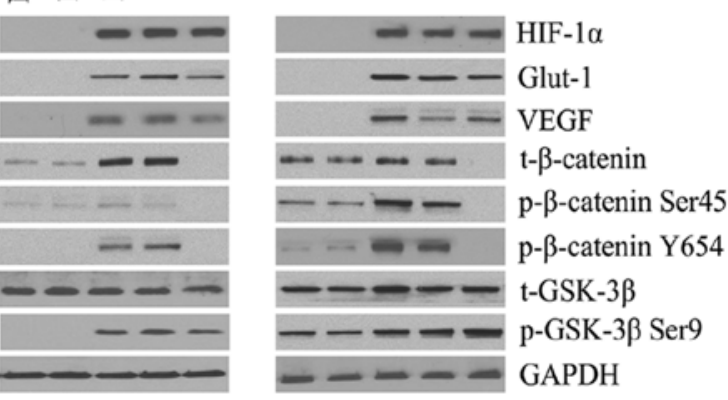

$\mathrm{B}$

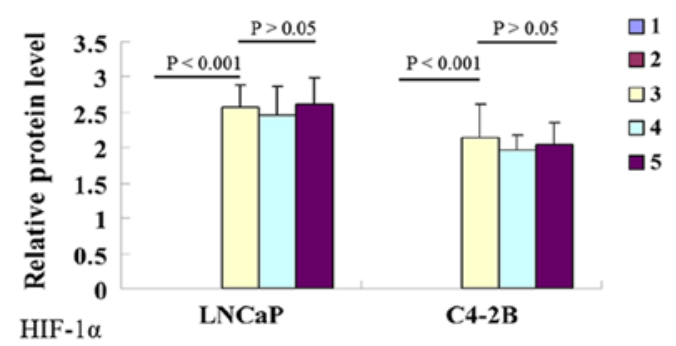

\section{$\mathrm{C}$}
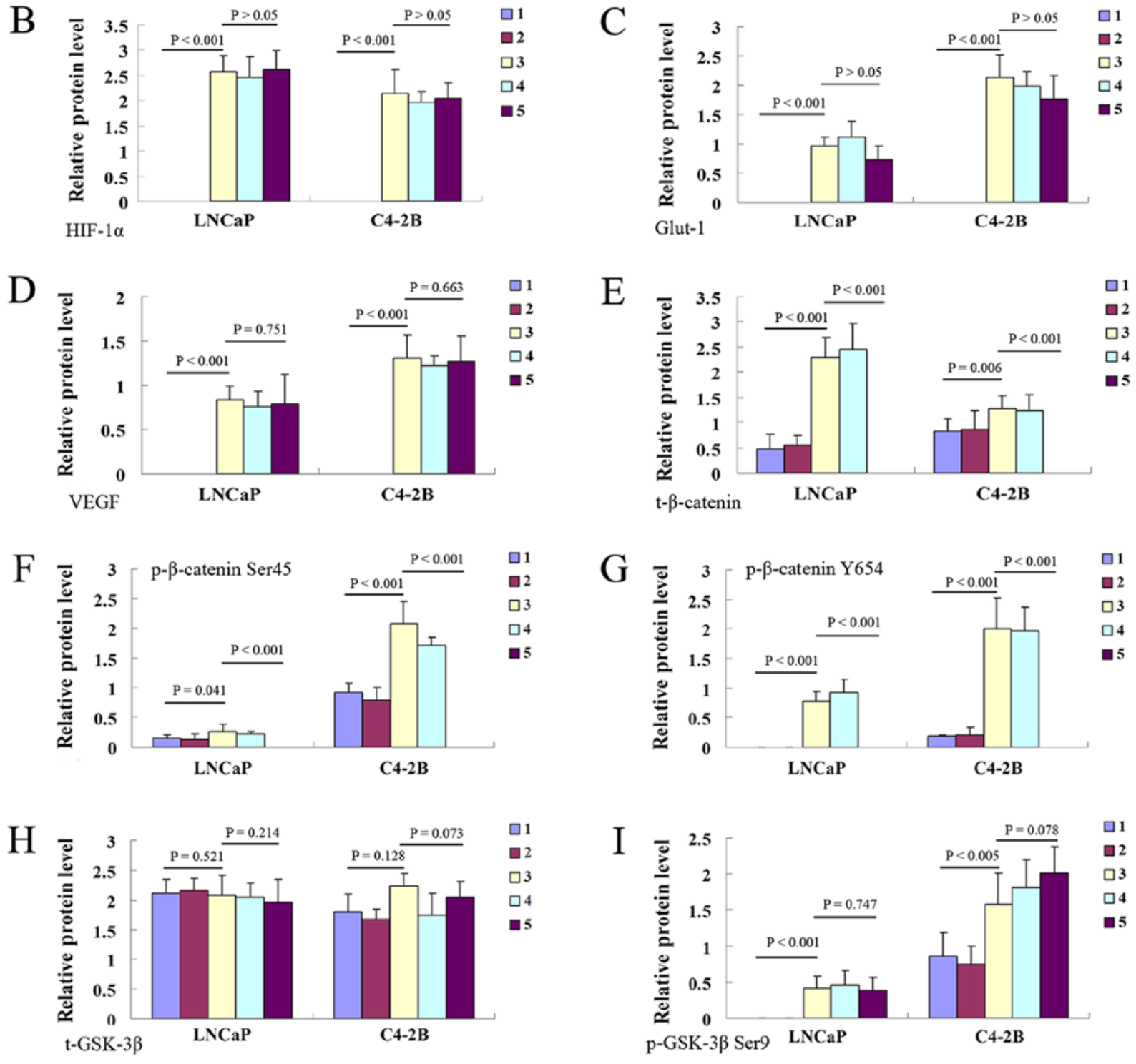

Figure 1. Effect of HIF-1 $\alpha$ overexpression on several functional proteins associated with $\beta$-catenin nuclear translocation in the prostate cancer cell lines, LNCaP and C4-2B. (A) Western blot analysis of the protein expression of HIF- $1 \alpha$, Glut- 1 , VEGF, t- $\beta$-catenin, $\mathrm{p}-\beta$-catenin-Ser45, $\mathrm{p}-\beta$-catenin-Y654, $\mathrm{t}-\mathrm{GSK}-3 \beta$ and p-GSK-3 $\beta$ Ser9 at $72 \mathrm{~h}$ in the negative control, HIF-1 $\alpha$ overexpression, $\beta$-catenin silenced and scrambled shRNA groups. (B-I) Statistic analysis of the expression of these functional proteins. Bar 1 indicates untreated cells, bar 2 indicates PcDNA3.1(-) control vector-transfected cells, bar 3 indicates PcDNA3.1(-)/HIF-1 $\alpha$ plasmid-transfected cells, bar 4 indicates HIF-1 $\alpha$-overexpressing cells transfected with PSuper-Scramble- $\beta$-catenin-ShRNA control vector, and bar 5 indicates HIF-1 $\alpha$-overexpressing cells transfected with PSuper- $\beta$-catenin-shRNA plasmid. 
(Boston, MA, USA) and maintained in a specific pathogenfree (SPF) class 100 clean room. Animal studies were conducted according to the recommendations outlined in the Guide for the Care and Use of Laboratory Animals in the Weatherall report. Animal experiments were approved by the Committee on the Ethics of Animal Experiments of the Capital Medical University, Beijing, China.

Orthotopic LNCaP tumor xenografts. The cells (3x10\%/animal; LNCaP-luc, LNCaP-luc/HIF-1 $\alpha$, or LNCaP-luc/HIF-1 $\alpha$ + shRNA) were injected orthotopically into the dorsolateral prostate of 4-week old athymic nude male mice. Approximately 2-6 weeks later, all mice were monitored using an IVIS Lumina Imaging System (Perkin-Elmer Life Sciences, Waltham, MA, USA). Mice with a strong luciferase bioluminescence signal $>5 \times 10^{6}$ were treated with radiation as described below. Tumor size was monitored every 5 days according using the luminescence signal.

Subcutaneous C4-2B tumor xenografts. The cells (C4-2B, C4-2B/HIF-1 $\alpha$ and C4-2B/HIF-1 $\alpha+$ shRNA) were re-suspended in serum-free DMEM, mixed 1:1 with Matrigel

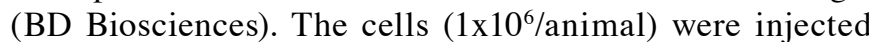
subcutaneously into the left flanks of previously castrated SCID mice (Charles River Laboratories, Wilmington, MA, USA). When palpable tumors reached a volume of $30-50 \mathrm{~mm}^{3}$, the mice were subjected to radiation as described below. Tumor size was monitored by measuring two dimensions and the volume was calculated by calculating length $\mathrm{x}$ width ${ }^{2} / 2$.

In vivo radiation treatment. The nice were irradiated using an Elekta6-MV photon linear accelerator. Five fractions of 2 Gy were delivered over 5 consecutive days for a total dose of $10 \mathrm{~Gy}$ with a dose rate of $1 \mathrm{~Gy} / \mathrm{min}$. After the final irradiation treatment, the mice were observed for 21 consecutive days. When the 21-day protocol was completed, all mice were euthanized by carbon dioxide inhalation, and the tumors were harvested. $\mathrm{CO}_{2}$ was displaced in the euthanisia chamber at the rate of $10-30 \%$ of chamber volume per min. Mice were also euthanized ahead of protocol if they became severely weak or if the tumor reached $20 \mathrm{~mm}$.

Immunohistochemistry. At the endpoint of animal protocol, tumors were harvested intactly and clearly, and then fixed by $4 \%$ paraformaldehyde for at least $24 \mathrm{~h}$. Subsequently, speciments were successively dehydrated by ethanol and treated by xylene. Finally, speciments were embedded by paraffin and prepared as $2-\mu \mathrm{m}$-thick slices for immunohistochemical staining. BRCA1 and Ki67 immunohistochemistry was carried out on formalin-fixed and paraffin-embedded tissue sections from the 21-day LNCaP and C4-2B tumor xenografts following in vivo radiation. After the tissue sections were de-paraffinized and rehydrated through graded alcohol, they were heated in a microwave in $0.01 \mathrm{~mol} / 1$ citrate buffer at $\mathrm{pH} 6.0$ for $10 \mathrm{~min}$ to retrieve antigens. Following a 30-min incubation in Dako protein blockage solution, the tissue sections were incubated in rabbit monoclonal antibodies against BRCA1 (1:250, ab16780; Abcam) or Ki67 (1:300, sc15402; Santa Cruz Biotechnology) for $90 \mathrm{~min}$, followed by incubation in a HRP polymer-conjugated secondary antibody (k4061; Dako, Glostrup, Denmark) for $40 \mathrm{~min}$. The immunoreaction was visualized in DAB/ $\mathrm{H}_{2} \mathrm{O}_{2}$. The specificity of the immunoreactions was verified by replacing the primary antibodies with PBS. Ten high-power fields were selected randomly in slides of each group using an image analysis system (Eclipse 90i; Nikon Instrument Inc., Tokyo, Japan), and the numbers of positively stained cells were counted using the Nikon NIS-Elements version 3.0 software and the percentage of positive cells was calculated.

Statistical analysis. Data are presented as the means \pm standard deviation and analyzed using ANOVA with Tukey's post hoc test. Statistical analysis was undertaken using SPSS 13.0 software for Windows (SPSS Inc., Chicago, IL, USA). Two-sided $\mathrm{P}$-values $<0.05$ were considered to indicate statistically significant differences.

\section{Results}

Transfection of the PCa cell lines, LNCaP and C4-2B, with $H I F-1 \alpha$ overexpression plasmid leads to $\beta$-catenin translocation to the nucleus. In both the LNCaP and C4-2B cells, the expression of HIF-1 $\alpha$ and its downstream regulatory proteins (Glut-1 and VEGF) was significantly increased $72 \mathrm{~h}$ following transfection with the HIF-1 $\alpha$ overexpression plasmid (Fig. 1A-D). In the HIF-1 $\alpha$ overexpression group, the total expression of $\beta$-catenin (Fig. 1A and E), the phosphorylation of Ser45 and Y654 of $\beta$-catenin (Fig. 1A, F and G), the total expression of GSK-3 $\beta$ (Fig. 1A and $\mathrm{H}$ ) and the phosphorylation of Ser9 of GSK-3 $\beta$ (Fig. 1A and I) were all significantly increased compared to the negative control group. By contrast, $\beta$-catenin expression and phosphorylation at Ser45 and Y654 were successfully inhibited in the $\beta$-catenin silenced group in both cell lines; however, the increased phosphorylation of GSK-3 $\beta$ Ser9 was not reversed by $\beta$-catenin silencing.

The immunofluorescence staining of $\beta$-catenin suggested that in negative control group, $\beta$-catenin expression was mainly found in the cytoplasm in both the $\mathrm{LNCaP}$ and $\mathrm{C} 4-2 \mathrm{~B}$ cells. In the HIF- $1 \alpha$ overexpression group, $\beta$-catenin expression was observed mainly in the nucleus, and the inhibition of $\beta$-catenin in the $\beta$-catenin silenced group led to diminished $\beta$-catenin staining (Fig. 2A and B). In both cell lines (Fig. 2C and D), the percentage of stained cells for $\beta$-catenin in the nucleus was significantly higher in the HIF-1 $\alpha$ overexpression group than in the negative control group ( $\mathrm{LNCaP}$ cells, $\mathrm{P}=0.0036$; $\mathrm{C} 4-2 \mathrm{~B}$ cells, $\mathrm{P}=0.0011$ ) and $\beta$-catenin silenced group ( $\mathrm{LNCaP}$ cells, $\mathrm{P}=0.0008$; $\mathrm{C} 4-2 \mathrm{~B}$ cells, $\mathrm{P}=0.0003$ ).

Downstream signals induced by HIF-1 $\alpha$ overexpression trigger $\beta$-catenin nuclear translocation. Western blot analysis of both the LNCaP and C4-2B cells revealed that the HIF-1 $\alpha$ overexpression group had a significantly reduced expression of the transmembrane epithelial proteins, E-cadherin and CK18, but an increased expression of the cytoplasmic mesenchymal proteins, vimentin, VEGFR, fibronectin and MMP-2 (Fig. 3A) compared with the two other groups. The in vitro invasion assay revealed that cell invasion was increased in the HIF-1 $\alpha$ overexpression group from 24 to $72 \mathrm{~h}$ compared with the negative control group ( $\mathrm{LNCaP}$ cells, $\mathrm{P}=0.0248$; $\mathrm{C} 4-2 \mathrm{~B}$ cells, $\mathrm{P}=0.0112$ ) and the $\beta$-catenin silenced group (LNCaP cells, $\mathrm{P}=0.0018$; $\mathrm{C} 4-2 \mathrm{~B}$ cells, $\mathrm{P}=0.0001)$ at $72 \mathrm{~h}$ in both cell lines 

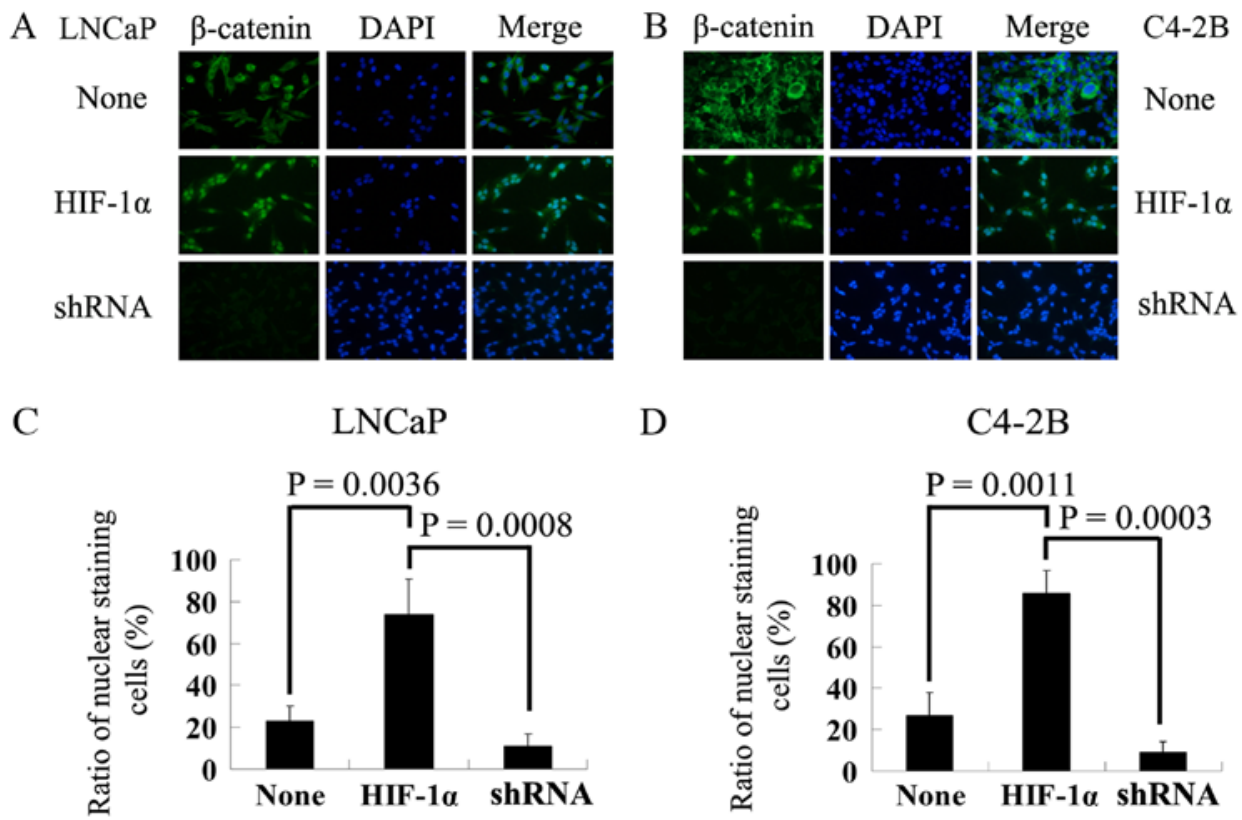

Figure 2. HIF-1 $\alpha$ transfection led to $\beta$-catenin translocation to the nucleus in the prostate cancer cell lines, LNCaP and C4-2B. (A and B) Immunofluorescence showing the expression and intercellular location of $\beta$-catenin at $72 \mathrm{~h}$ in the negative control, HIF-1 $\alpha$ overexpression and $\beta$-catenin silenced groups. $(\mathrm{C}$ and $\mathrm{D})$ Nuclear expression of $\beta$-catenin at $72 \mathrm{~h}$ in the negative control, HIF-1 $\alpha$ overexpression and $\beta$-catenin silenced groups.

A

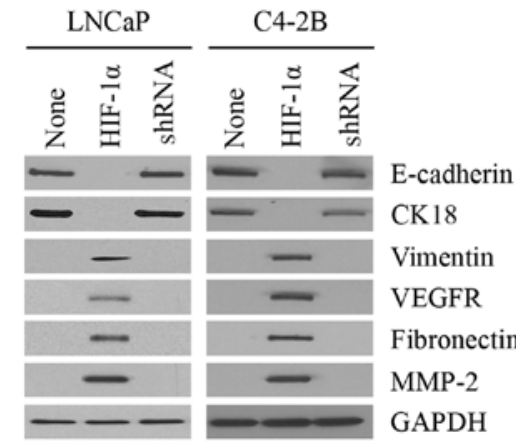

$\mathrm{C}$

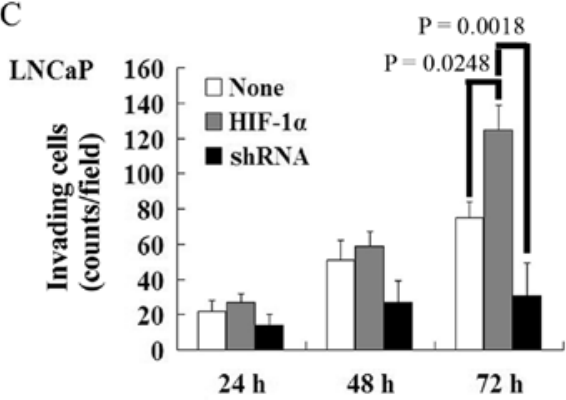

E

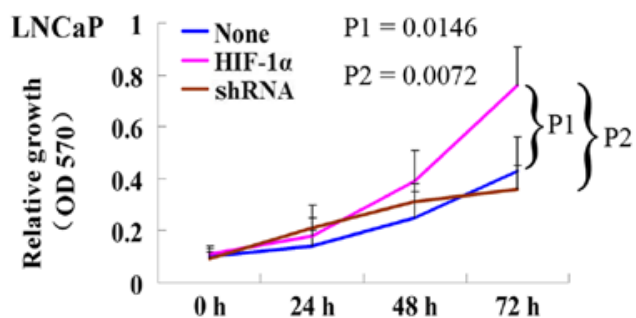

B

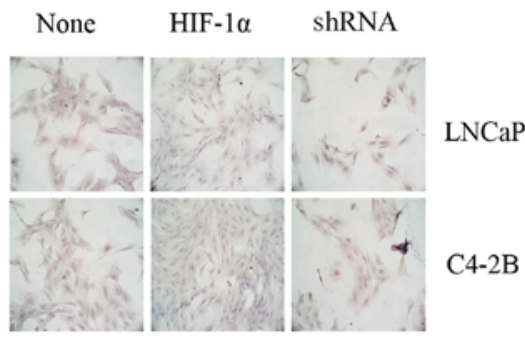

$\mathrm{D}$

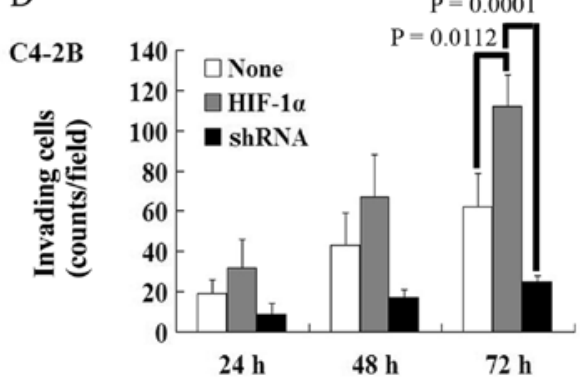

$\mathrm{F}$

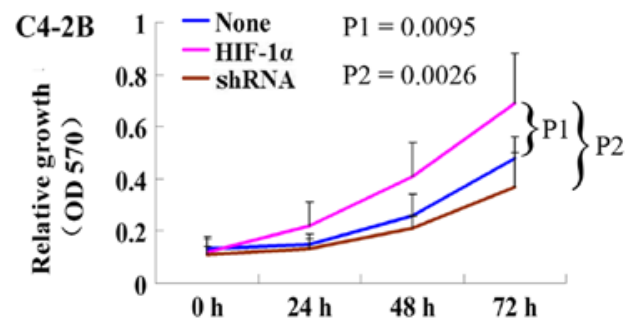

Figure 3. Effect of activation of the HIF-1 $\alpha / \beta$-catenin signaling pathway on the biological behavior in the prostate cancer cell lines, LNCaP and C4-2B. (A) Western blot analysis of the protein expression of epithelial transmembrane proteins (E-cadherin and CK18) and mesenchymal cytoplasm proteins (vimentin, VEGF, fibronectin and MMP-2) at $72 \mathrm{~h}$. (B) Images of invasion assays in the negative control, HIF-1 $\alpha$ overexpression and $\beta$-catenin silenced groups at $72 \mathrm{~h}$. (C and D) Cell count of invasion assays in the negative control, HIF-1 $\alpha$ overexpression and $\beta$-catenin silenced groups of LNCaP and C4-2B cells at 24, 48 and $72 \mathrm{~h}$. (E and F) MTT assays in the negative control, HIF-1 $\alpha$ overexpression and $\beta$-catenin silenced groups at 24,48 and $72 \mathrm{~h}$. 
A

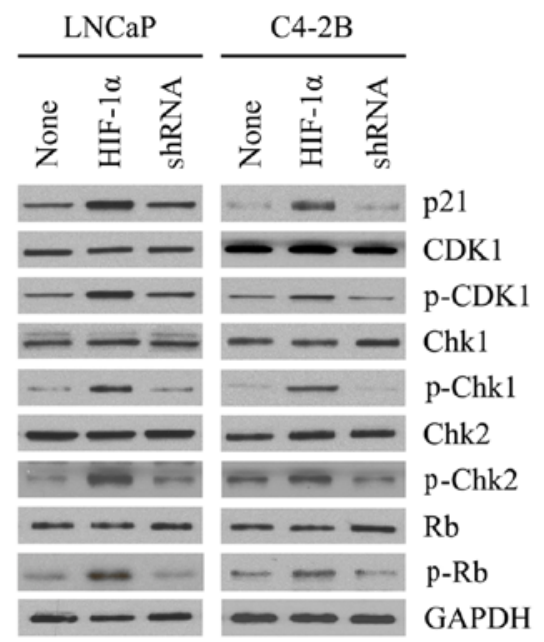

B
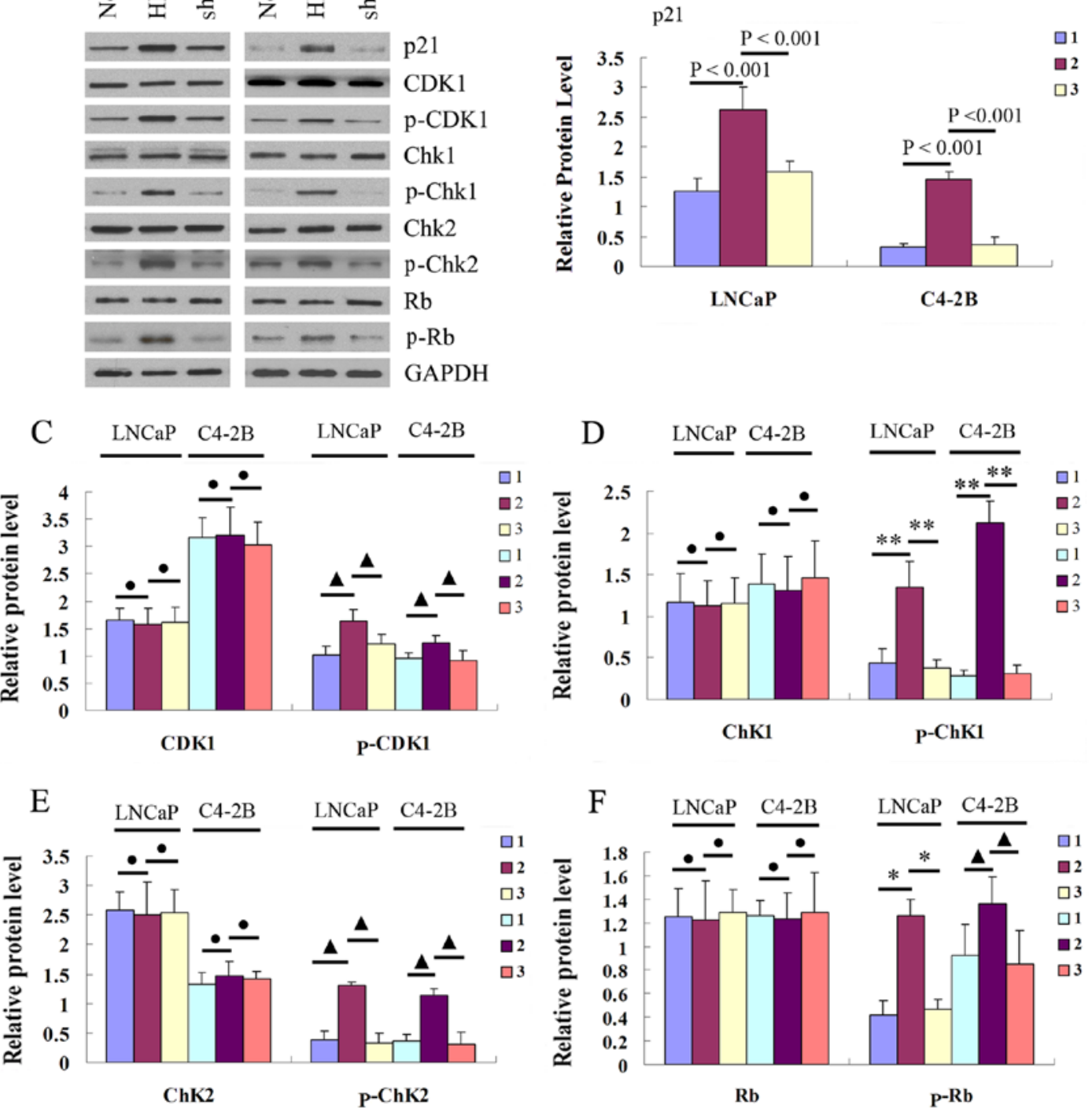

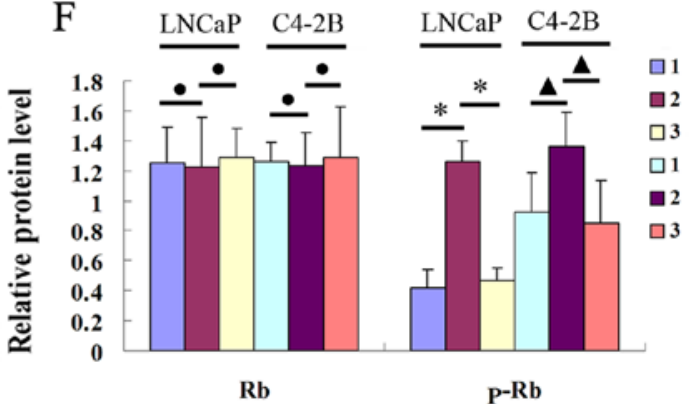

Figure 4. Effect of $\beta$-catenin nuclear translocation on cell cycle distribution in the prostate cancer cell lines, LNCaP and C4-2B. (A) Western blot analysis of the protein expression of cell cycle regulatory proteins, including p21, CDK1, p-CDK1, Chk1, p-Chk1, Chk2, p-Chk2, Rb and p-Rb at $72 \mathrm{~h}$ in the negative control, HIF-1 $\alpha$ overexpression and $\beta$-catenin silenced groups of LNCaP and C4-2B cells. (B-F) Statistic analysis of the expression of cell cycle regulators. Bar 1 indicates untreated cells, bar 2 indicates PcDNA3.1(-)/HIF-1 $\alpha$ plasmid transfected cells, and bar 3 indicates HIF-1 $\alpha$ high expression cells transfected with PSuper- $\beta$-catenin-shRNA plasmid. ${ }^{\bullet} \mathrm{P}>0.05 ;{ }^{\wedge} \mathrm{P}<0.05 ;{ }^{*} \mathrm{P}<0.01 ;{ }^{* *} \mathrm{P}<0.001$.

(Fig. 3B-D). Furthermore, the above-mentioned observations were associated with an increased cell proliferation in the HIF-1 $\alpha$ overexpression group from 0 to $72 \mathrm{~h}$ compared with the negative control group ( $\mathrm{LNCaP}$ cells, $\mathrm{P}=0.0146$; $\mathrm{C} 4-2 \mathrm{~B}$ cells, $\mathrm{P}=0.0095)$ and $\beta$-catenin silenced group ( $\mathrm{LNCaP}$ cells, $\mathrm{P}=0.0072 ; \mathrm{C} 4-2 \mathrm{~B}$ cells, $\mathrm{P}=0.0026)$ at $72 \mathrm{~h}$, based on the results of MTT assay (Fig. 3E and F).

Effect of $\beta$-catenin nuclear translocation on cell cycle distribution, apoptosis, and NHEJ repair. Western blot analysis of both the LNCaP and C4-2B cells revealed that the phosphorylation of cell cycle regulators (including CDK1, Chk1, Chk2 and $\mathrm{Rb}$ ) was significantly enhanced at $72 \mathrm{~h}$ in the HIF-1 $\alpha$ overexpression group compared with the other 2 groups $(\mathrm{P}<0.05)$, while the total expression of each of these proteins did not differ among the 3 groups (Fig. 4).
Flow cytometric analysis (Fig. 5A and B) revealed that transfection with the HIF-1 $\alpha$ overexpression plasmid decreased the percentage of cells in the sub-G1 phase (LNCaP cells, $\mathrm{P}=0.038 ; \mathrm{C} 4-2 \mathrm{~B}$ cells, $\mathrm{P}=0.047)$ and $\mathrm{G} 2 / \mathrm{M}$ phase $(\mathrm{LNCaP}$ cells, $\mathrm{P}=0.0411$; $\mathrm{C} 4-2 \mathrm{~B}$ cells, $\mathrm{P}=0.0627)$, and increased the percentage of cells in the G0/G1 phase (LNCaP cells, $\mathrm{P}=0.0294 ; \mathrm{C} 4-2 \mathrm{~B}$ cells, $\mathrm{P}=0.3615$ ) and $\mathrm{S}$ phase (LNCaP cells, $\mathrm{P}=0.0137$; $\mathrm{C} 4-2 \mathrm{~B}$ cells, $\mathrm{P}=0.0185)$, compared with the negative control. In addition, $\beta$-catenin knockdown resulted in a greater distribution of sub-G1 cells ( $\mathrm{LNCaP}$ cells, $\mathrm{P}=0.0016$; $\mathrm{C} 4-2 \mathrm{~B}$ cells, $\mathrm{P}=0.0009$ ) and a reduction in the $\mathrm{G} 0 / \mathrm{G} 1$ cell population ( $\mathrm{LNCaP}$ cells, $\mathrm{P}=0.0009$; $\mathrm{C} 4-2 \mathrm{~B}$ cells, $\mathrm{P}=0.0003$ ) compared with the HIF-1 $\alpha$ overexpression group in both the LNCaP and C4-2B cells.

Western blot analysis of both the LNCaP and C4-2B cells revealed that the protein expression of apoptotic regulators 
A LNCaP cells
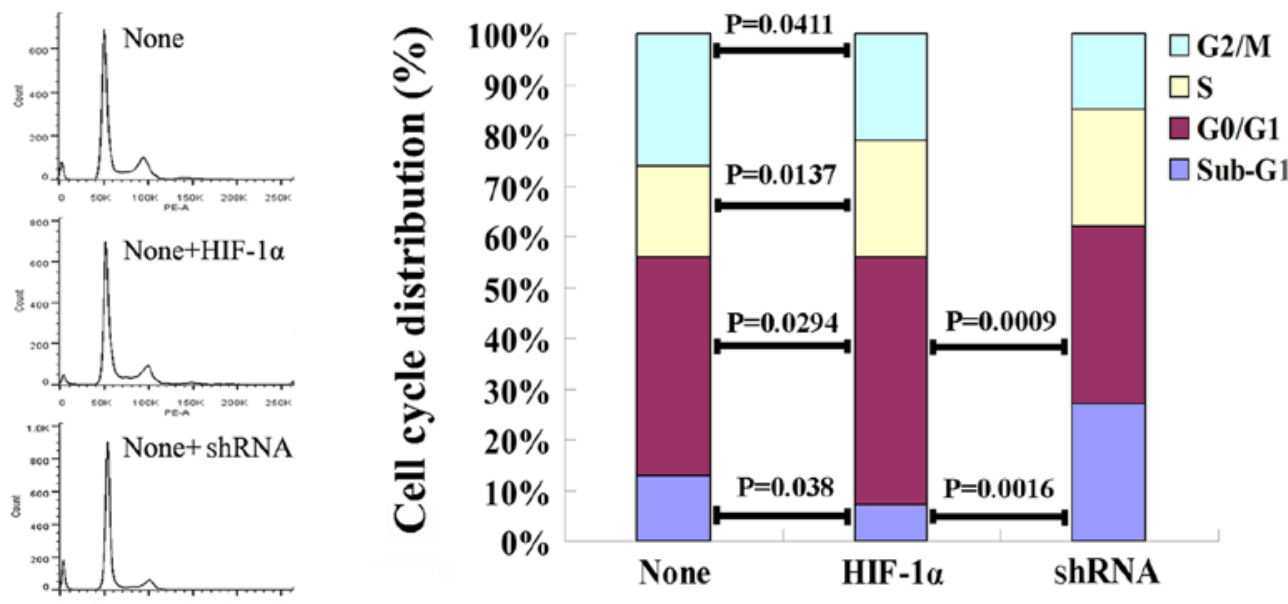

B
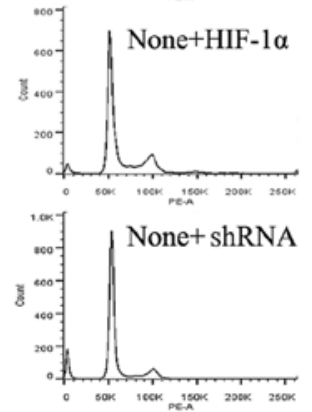

$20 \%$

$10 \%$

C4-2B cells
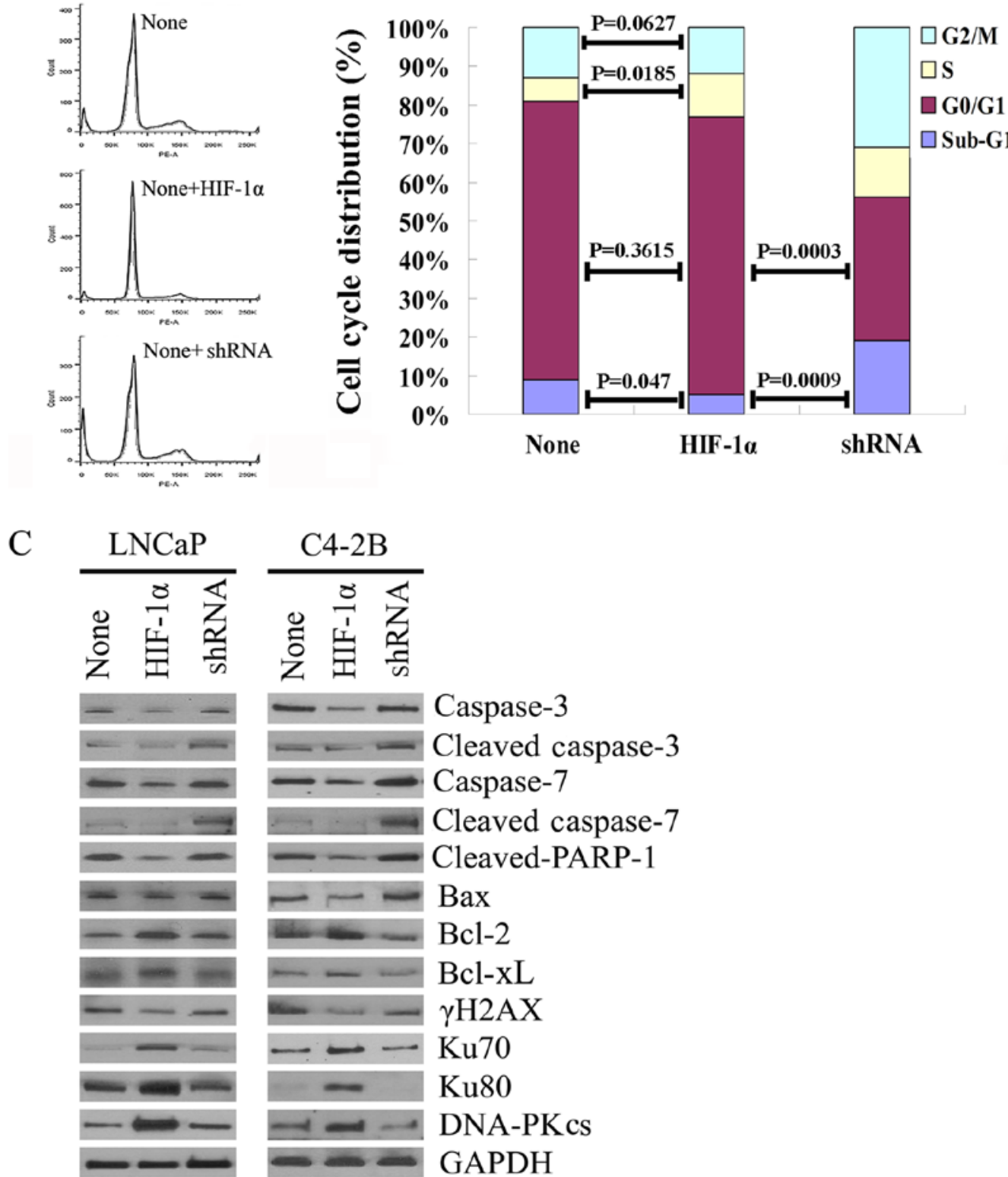

Figure 5. Effect of $\beta$-catenin nuclear translocation on apoptosis and non-homologous end joining (NHEJ) repairing potential in the prostate cancer cell lines, LNCaP and C4-2B. (A and B) Flow cytometric analysis of the cell cycle distribution (G0/G1, S and G2/M phase) at $72 \mathrm{~h}$ in the negative control, HIF-1 $\alpha$ overexpression and $\beta$-catenin silenced groups. (C) Western blot analysis of the protein expression of apoptotic regulators (including caspase-3, cleaved-caspase-3, caspase-7, cleaved-caspase-7, cleaved-PARP-1 and Bax), anti-apoptotic proteins (Bcl-2 and Bcl-xL), the DNA double strand breaks (DSB) marker, $\gamma$ H2AX, and NHEJ repair proteins (Ku70, Ku80 and DNA-PKcs) at $72 \mathrm{~h}$ in the negative control, HIF-1 $\alpha$ overexpression and $\beta$-catenin silenced groups. 
A
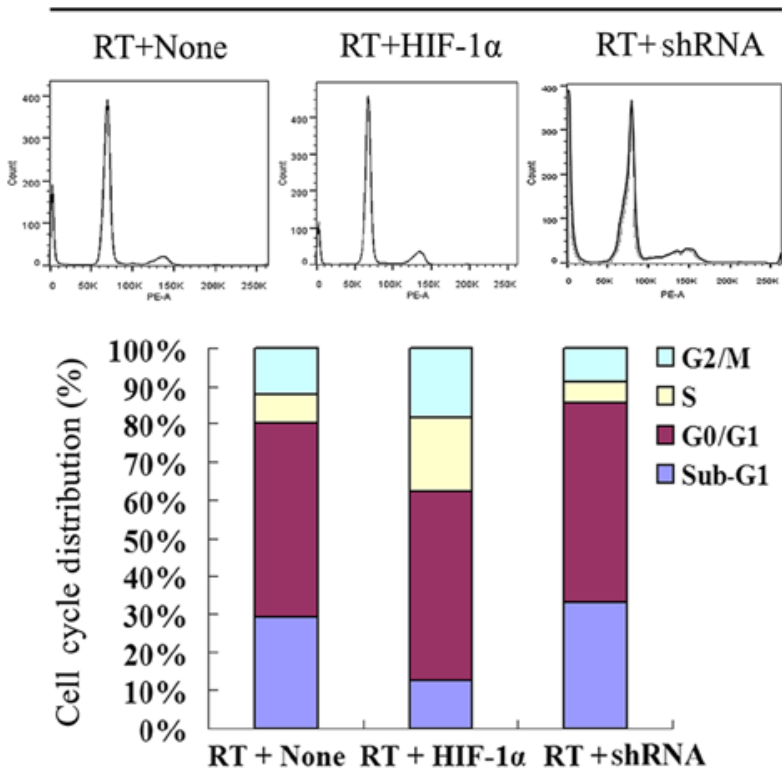

C

LNCaP

$\square$ None $\square$ RT

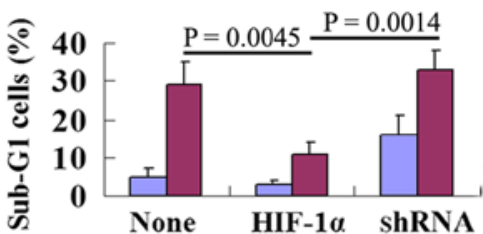

E LNCaP

$\square$ None $\square$ RT

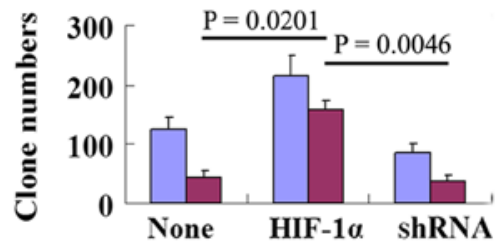

G

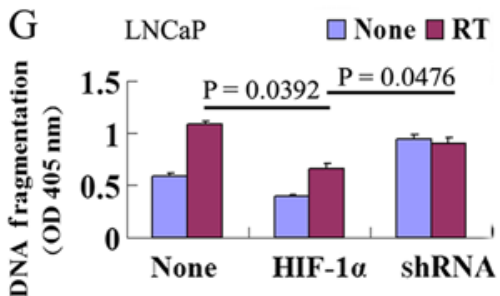

D

C4-2B

F

C4-2B
B

C4-2B

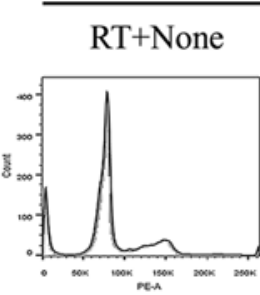

RT + HIF- $1 \alpha$

$\mathrm{RT}+$ shRNA
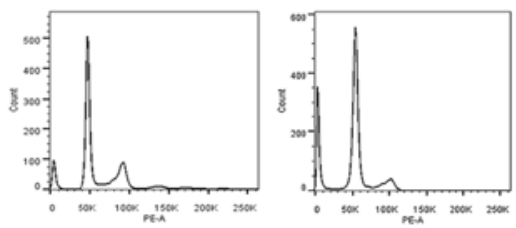

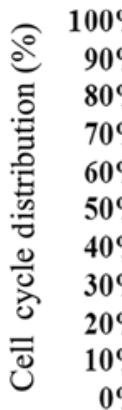

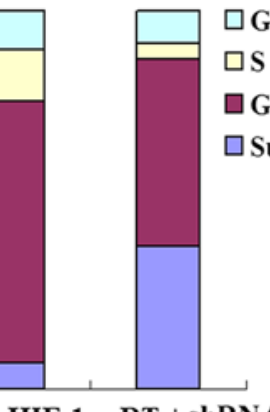

RT + None RT + HIF-1 $\alpha$ RT + shRNA

$\square \mathrm{G} 2 / \mathrm{M}$

$\square \mathrm{S}$

$\square \mathrm{G} 0 / \mathrm{G} 1$

$\square$ Sub-G1

$\square$ None $\square$ RT

I
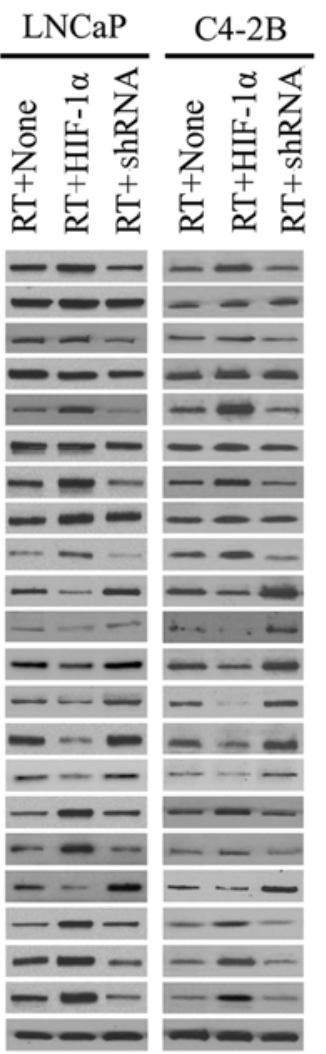

p21

CDK1

$\square$ None $\square$ RT

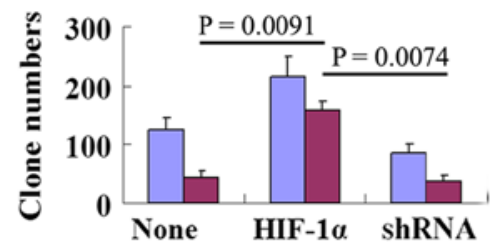

Chk1

p-Chk1

Chk2

p-Chk2

$\mathrm{Rb}$

$\mathrm{p}-\mathrm{Rb}$

Caspase-3

Cleaved caspase-3

Caspase-7

Cleaved caspase-7

Cleaved-PARP-1

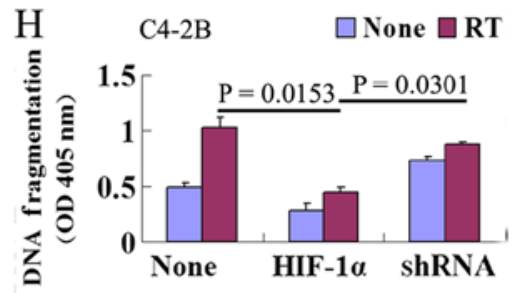

Bax

Bcl-2

Bcl-xL

$\gamma \mathrm{H} 2 \mathrm{AX}$

$\mathrm{Ku} 70$

Ku80

DNA-PKes

GAPDH

Figure 6. Effect of $\beta$-catenin nuclear translocation on cell cycle distribution, apoptosis and non-homologous end joining (NHEJ) repair following irradiation (A-D) Results of flow cytometry of the cell cycle distribution and sub-G1 cell ratio at $72 \mathrm{~h}$ in the negative control, HIF-1 $\alpha$ overexpression and $\beta$-catenin silenced groups of LNCaP and $\mathrm{C} 4-2 \mathrm{~B}$ cells following in vitro irradiation. (E and F) Colony formation assay showing colony-forming capability at $72 \mathrm{~h}$ in the negative control, HIF- $1 \alpha$ overexpression and $\beta$-catenin silenced groups of LNCaP and C4-2B cells following in vitro irradiation. (G and $\mathrm{H}$ ) ELISA results at $72 \mathrm{~h}$ showing cell death (DNA fragmentation) in the negative control, HIF-1 $\alpha$ overexpression and $\beta$-catenin silenced groups of LNCaP and C4-2B cells following in vitro irradiation. (I) Western blot analysis of the protein expression of cell cycle regulators (p21, CDK1, p-CDK1, Chk1, p-Chk1, Chk2, p-Chk2, Rb and $\mathrm{p}-\mathrm{Rb}$ ), apoptotic proteins (including caspase-3, cleaved-caspase-3, caspase-7, cleaved-caspase-7, cleaved-PARP-1 and Bax), anti-apoptotic proteins (Bcl-2 and $\mathrm{Bcl}-\mathrm{xL}$ ), the DNA double strand breaks (DSB) marker, $\gamma \mathrm{H} 2 \mathrm{AX}$, and non-homologous end joining (NHEJ) repair proteins (Ku70, Ku80 and DNA-PKCs) at $72 \mathrm{~h}$ in the negative control, HIF-1 $\alpha$ overexpression and $\beta$-catenin silenced groups of $\mathrm{LNCaP}$ and $\mathrm{C} 4-2 \mathrm{~B}$ cells following in vitro irradiation.

(including caspase-3, cleaved-caspase-3, caspase-7, cleavedcaspase-7, cleaved-PARP-1 and Bax) and the DSB marker $(\gamma \mathrm{H} 2 \mathrm{AX})$ was decreased at $72 \mathrm{~h}$ in the HIF-1 $\alpha$ overexpression group compared with the other 2 groups. By contrast, the protein expression levels of anti-apoptotic proteins (including Bcl-2 and Bcl-xL) and NHEJ repair proteins (including Ku70, Ku80 
A

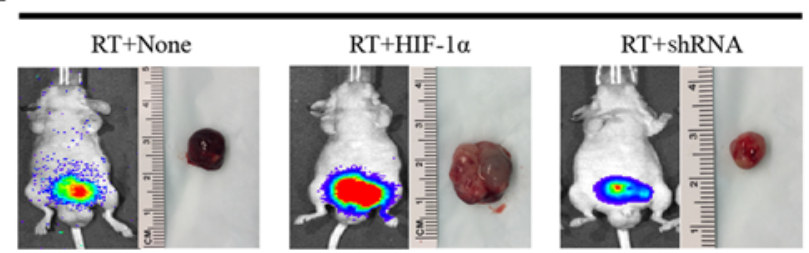

$\mathrm{B}$

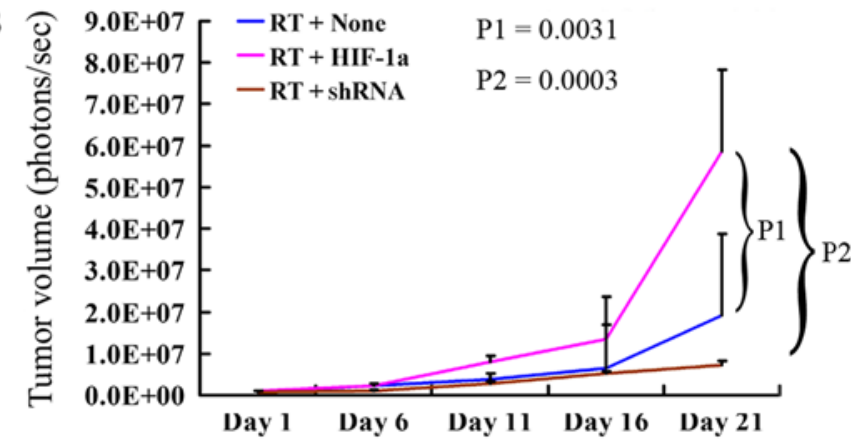

C

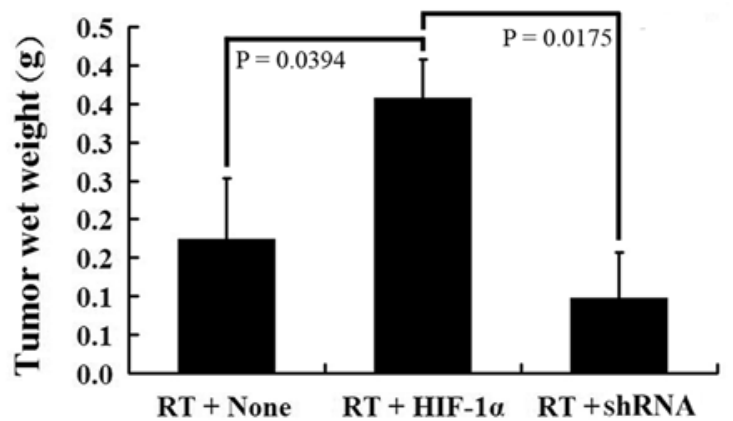

$\mathrm{D}$

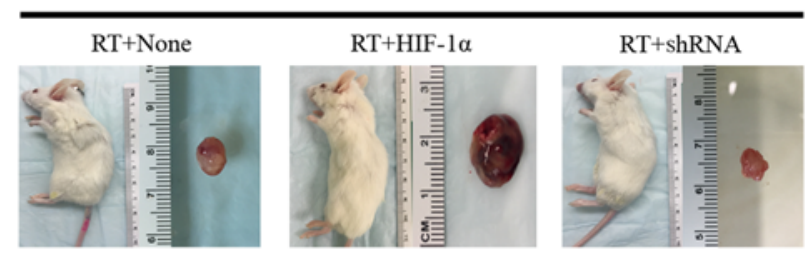

$\mathrm{E}$

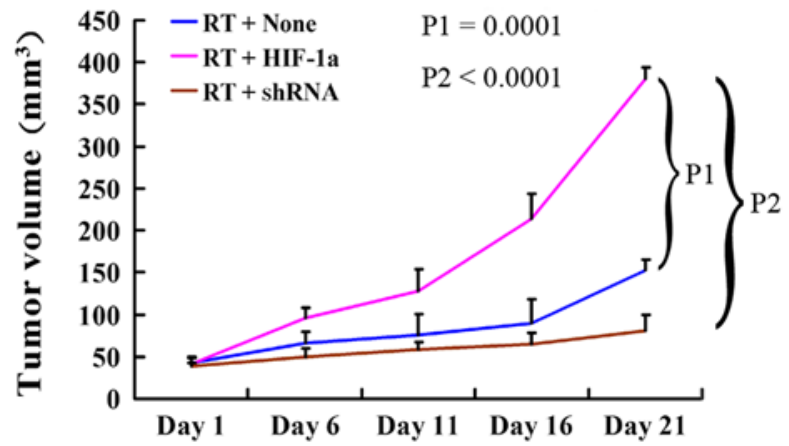

$\mathrm{F}$

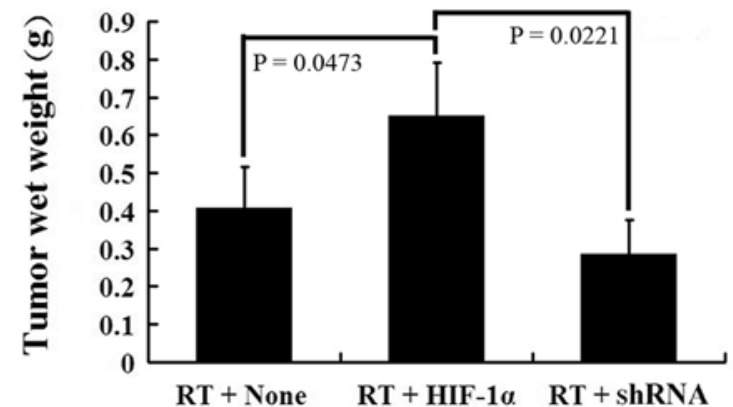

Figure 7. Effect of $\beta$-catenin nuclear translocation on tumor growth following in vivo irradiation in mice. (A and B) Luminescence signal intensity representing tumor volume measured at 1, 6, 11, 16 and 21 days in the negative control, HIF-1 $\alpha$ overexpression, and $\beta$-catenin silenced groups of the LNCaP orthotopic model using BALB/c-nu mice following irradiation. (C) Tumor wet weight on day 21 in the negative control, HIF-1 $\alpha$ overexpression and $\beta$-catenin silenced groups of the LNCaP orthotopic model using BALB/c-nu mice following irradiation. (D and E) Vital imaging of tumor and tumor volume at 1,6 , 11,16 and 21 days in the negative control, HIF-1 $\alpha$ overexpression and $\beta$-catenin silenced groups of the C4-2B subcutaneous model using SCID mice following irradiation. (F) Tumor wet weight on day 21 in the negative control, HIF-1 $\alpha$ overexpression and $\beta$-catenin silenced groups of the C4-2B subcutaneous model using SCID mice following irradiation ( $\mathrm{n}=15 / \mathrm{group})$.

and DNA-PKcs) was increased in the HIF-1 $\alpha$ overexpression group compared with the other 2 groups (Fig. 5C). In addition, the expression of the above-mentioned apoptotic regulators, anti-apoptotic proteins, and NHEJ repair proteins was similar between the $\beta$-catenin silenced and negative control groups.

Effect of $\beta$-catenin nuclear translocation on cell cycle distribution, apoptosis and NHEJ repair following irradiation. The results of flow cytometric assay (Fig. 6A-D) revealed that in the both LNCaP and C4-2B cells following irradiation treatment, the HIF-1 $\alpha$ overexpression group had a significantly greater $\mathrm{S}$ phase cell population ( $\mathrm{LNCaP}$ cells, $\mathrm{P}=0.0092$; $\mathrm{C} 4-2 \mathrm{~B}$ cells, $\mathrm{P}=0.0027)$ and a decreased sub-G1 cell population ( $\mathrm{LNCaP}$ cells, $\mathrm{P}=0.0045$; $\mathrm{C} 4-2 \mathrm{~B}$ cells, $\mathrm{P}=0.0039$ ) compared with the negative control group. $\beta$-catenin silencing markedly reversed the effects of HIF-1 $\alpha$ transfection and led to a decrease in the $\mathrm{S}$ phase cell population ( $\mathrm{LNCaP}$ cells, $\mathrm{P}=0.0045$; $\mathrm{C} 4-2 \mathrm{~B}$ cells, $\mathrm{P}=0.0006)$ and an increase in the sub-G1 cell population ( $\mathrm{LNCaP}$ cells, $\mathrm{P}=0.0014$; $\mathrm{C} 4-2 \mathrm{~B}$ cells, $\mathrm{P}=0.0003$ ).

In addition, the results of colony formation assay revealed an approximately 4 -fold greater number of clones in the
HIF-1 $\alpha$ overexpression group than in the negative control group ( $\mathrm{LNCaP}$ cells, $\mathrm{P}=0.0201 ; \mathrm{C} 4-2 \mathrm{~B}$ cells, $\mathrm{P}=0.0091$ ) and $\beta$-catenin silenced group ( $\mathrm{LNCaP}$ cells, $\mathrm{P}=0.0046 ; \mathrm{C} 4-2 \mathrm{~B}$ cells, $\mathrm{P}=0.0074$ ) at $72 \mathrm{~h}$, while no significant differences were observed between the $\beta$-catenin silenced and negative control groups (Fig. 6E and F).

DNA fragmentation was significantly lower in the HIF-1 $\alpha$ overexpression group than in the negative control group ( $\mathrm{LNCaP}$ cells, $\mathrm{P}=0.0392 ; \mathrm{C} 4-2 \mathrm{~B}$ cells, $\mathrm{P}=0.0153)$ and $\beta$-catenin silenced group ( $\mathrm{LNCaP}$ cells, $\mathrm{P}=0.0476$; $\mathrm{C} 4-2 \mathrm{~B}$ cells, $\mathrm{P}=0.0301$ ) at $72 \mathrm{~h}$ in both the LNCaP and C4-2B cells following irradiation treatment (Fig. 6G and $\mathrm{H}$ ).

Similar to the above-mentioned experiments without radiation in both the LNCaP and C4-2B cells, the post-irradiation expression of cell cycle regulators (including p21, p-CDK1, p-Chk1, p-Chk2 and p-Rb) was significantly enhanced at $72 \mathrm{~h}$ in the HIF-1 $\alpha$ group overexpression compared with the $\beta$-catenin silenced and negative control groups, while the total expression of each of these proteins did not differ among the 3 groups. Additionally, the post-irradiation protein expression of apoptotic regulators (including caspase-3, cleaved-caspase-3, 
A

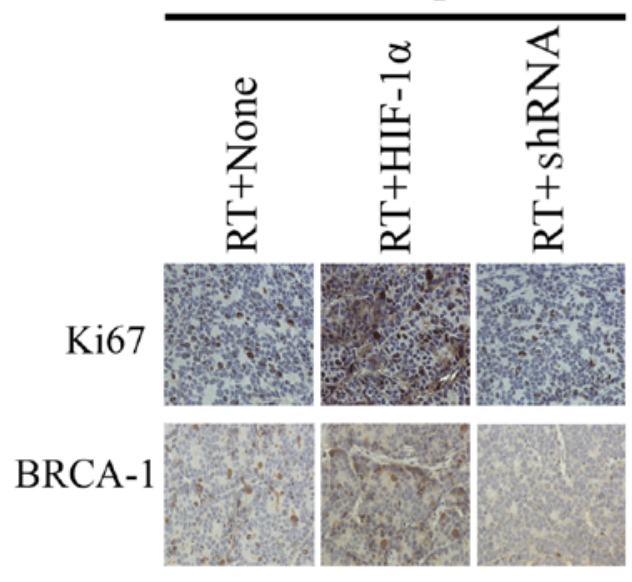

$\mathrm{B}$

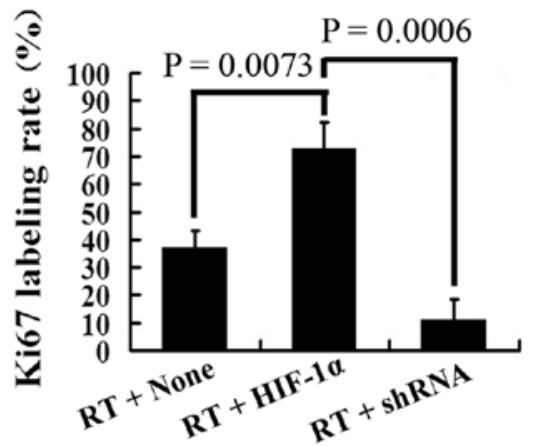

C

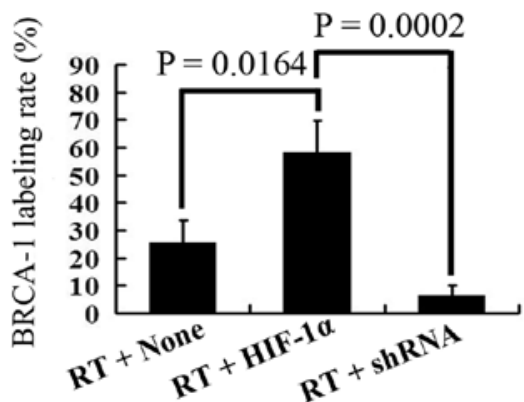

D C4-2B subcutaneous model
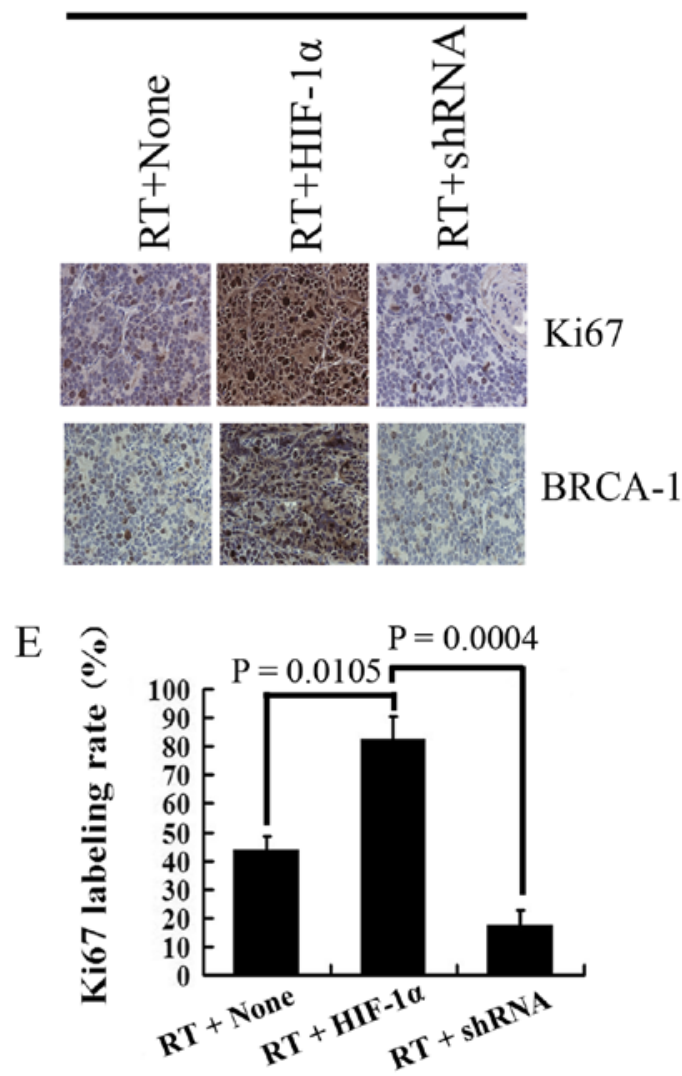

F

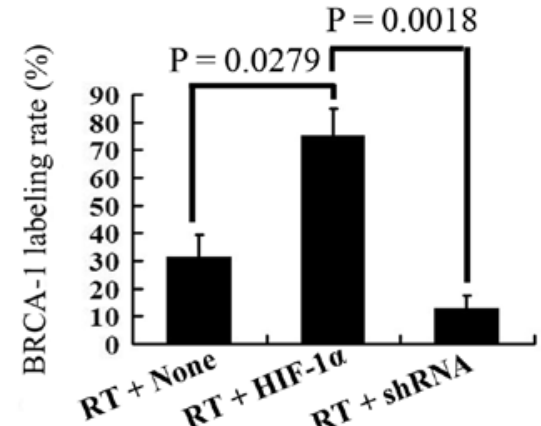

Figure 8. Effect of $\beta$-catenin nuclear translocation on tumor proliferation after in vivo irradiation in mice. (A) Immunohistochemistry of Ki67 and BRCA-1 in the negative control, HIF-1 $\alpha$ overexpression and $\beta$-catenin silenced groups of the LNCaP orthotopic model using BALB/c-nu mice following irradiation. (B) Ratio of Ki67-positive cells in the negative control, HIF-1 $\alpha$ overexpression and $\beta$-catenin silenced groups of LNCaP orthotopic model using BALB/c-nu mice following irradiation. (C) Ratio of BRCA-1-positive cells in the negative control, HIF-1 $\alpha$ overexpression and $\beta$-catenin silenced groups of the LNCaP orthotopic model using BALB/c-nu mice after irradiation. (D) Immunohistochemistry of Ki67 and BRCA-1 in the negative control, HIF-1 $\alpha$ overexpression and $\beta$-catenin silenced groups of the C4-2B subcutaneous model using SCID mice following irradiation. (E) Ratio of Ki67-positive cells in the negative control, HIF-1 $\alpha$ overexpression and $\beta$-catenin silenced groups of the C4-2B subcutaneous model using SCID mice following irradiation. (F) Ratio of BRCA-1-positive cells in the negative control, HIF-1 $\alpha$ overexpression and $\beta$-catenin silenced groups of the C4-2B subcutaneous model using SCID mice following irradiation ( $\mathrm{n}=15 /$ group).

caspase-7, cleaved-caspase-7, cleaved-PARP-1 and Bax) and the DNA DSB marker $(\gamma \mathrm{H} 2 \mathrm{AX})$ was decreased at $72 \mathrm{~h}$ in the HIF-1 $\alpha$ overexpression group compared with the other 2 groups. By contrast, the protein expression of anti-apoptotic proteins (including $\mathrm{Bcl}-2$ and $\mathrm{Bcl}-\mathrm{xL}$ ), and $\mathrm{NHEJ}$ repair proteins (including $\mathrm{Ku} 70, \mathrm{Ku} 80$ and DNA-PKcs) was increased in the HIF-1 $\alpha$ overexpression group compared with the $\beta$-catenin silenced and negative control groups (Fig. 6I). In addition, the expression of the above apoptotic regulators, anti-apoptotic proteins, and NHEJ repair proteins was similar between the $\beta$-catenin silencing and negative control groups.
Effect of $\beta$-catenin nuclear translocation on tumor growth following in vivo irradiation in mice. The in vivo imaging of orthotopic models indicated that HIF-1 $\alpha$-overexpressing LNCaP cells produced tumors with a 3 -fold greater volume $(\mathrm{P}=0.0031)$ and a 2 -fold greater wet weight $(\mathrm{P}=0.0394)$ than those produced by the negative control cells on day 21 . The cells in which $\beta$-catenin was silenced produced tumors with a reduced tumor volume $(\mathrm{P}=0.0003)$ and tumor wet weight $(\mathrm{P}=0.0175)$ than the HIF-1 $\alpha$-overexpressing cells (Fig. 7A-C). In addition, the $\mathrm{C} 4-2 \mathrm{~B}$ subcutaneous models exhibited similar tumor-promoting effects induced by HIF-1 $\alpha$-overexpressing 
cells (tumor volume, $\mathrm{P}=0.0001$; and wet weight, $\mathrm{P}=0.0473$ ); in addition, the cells in which $\beta$-catenin was silenced also produced tumors with a lower volume and wet weight (tumor volume, $\mathrm{P}<0.0001$; and wet weight, $\mathrm{P}=0.0221$ ), similarly as in the $\mathrm{LNCaP}$ orthotopic tumor xenograft model with regard to tumor volume and tumor wet weight (Fig. 7D-F).

Effect of $\beta$-catenin nuclear translocation on tumor proliferation following in vivo irradiation in mice. The results of immunohistochemistry revealed that the expression of Ki67 and BRCA-1 was significantly increased in the HIF-1 $\alpha$ overexpression group compared with the negative control group (Ki67: $\mathrm{LNCaP}$ cells, $\mathrm{P}=0.0073$; $\mathrm{C} 4-2 \mathrm{~B}$ cells, $\mathrm{P}=0.0105$; BRCA-1: LNCaP cells, $\mathrm{P}=0.0164$; $\mathrm{C} 4-2 \mathrm{~B}$ cells, $\mathrm{P}=0.0279$ ) on day 21 in both the LNCaP orthotopic and $\mathrm{C} 4-2 \mathrm{~B}$ subcutaneous in vivo irradiation models. After $\beta$-catenin was silenced, the expression levels of $\mathrm{Ki} 67$ and BRCA-1 were both decreased (Ki67: LNCaP cells, $\mathrm{P}=0.0006$; $\mathrm{C} 4-2 \mathrm{~B}$ cells, $\mathrm{P}=0.0004$; BRCA-1: LNCaP cells, $\mathrm{P}=0.0002$; $\mathrm{C} 4-2 \mathrm{~B}$ cells, $\mathrm{P}=0.0018)$ compared with the HIF-1 $\alpha$ overexpression group (Fig. 8).

\section{Discussion}

Although recent studies have suggested that the activation of the FGFR/PLC $\gamma$ signaling pathway (23) induced by HIF-1 $\alpha$ or the functional interplay of the ERKs/DNA-PKcs signaling pathway (24) with HIF-1 $\alpha$ exerts an independent effect on radioresistance in malignant tumors, the molecular mechanisms responsible for the radioresistance promoted by HIF-1 $\alpha$ remain unclear.

$\beta$-catenin is involved in the PCa metastatic cascade. Therefore, this study aimed to investigate the role of HIF-1 $\alpha$ and $\beta$-catenin in radioresistance in $\mathrm{PCa}$. The results revealed that HIF- $1 \alpha$ overexpression led to $\beta$-catenin activation and nuclear translocation in the PCa cell lines, LNCaP and C4-2B, and in turn this upregulated cell proliferation and cell invasion, increased cell cycle distribution at the G0/G1 phase, reduced apoptosis/DNA fragmentation, and enhanced DNA NHEJ repairing activity. By contrast, $\beta$-catenin silencing reversed these changes. Following irradiation, $\beta$-catenin activation reduced DNA fragmentation and enhanced colony formation, which was reversed by $\beta$-catenin silencing. Orthotopic and subcutaneous tumor models further confirmed that tumor growth was the highest in the HIF-1 $\alpha$ overexpression tumor models and the lowest in the $\beta$-catenin silenced tumor models. Taken together, these results strongly suggest that $\beta$-catenin nuclear translocation is a key process in the radioresistance of PCa.

Cojoc et al found that acquired radioresistance was associated with the loss of E-cadherin expression and the increased expression of $\beta$-catenin (18). The present study also demonstrated that HIF-1 $\alpha$ overexpression led to the loss of E-cadherin, while it enhanced $\beta$-catenin nuclear translocation, which is of importance, as E-cadherin binding to $\beta$-catenin keeps $\beta$-catenin in the cytoplasm and prevents its nuclear translocation, while HIF-1 $\alpha$ can suppress the expression of E-cadherin by upregulating Snail $(25,26)$. Therefore, the expression of E-cadherin and $\beta$-catenin is both regulated by HIF-1 $\alpha$. In other type of cancer (such as lung cancer and rectal adenocarcinoma), $\beta$-catenin has been found to regulate tumor radioresistance $(27,28)$. Wang et al were able to use the overexpression ( $>50 \%$ of positive tumor cells) of nuclear $\beta$-catenin to predict radioresistance in patients with rectal adenocarcinoma and achieved $83 \%$ accuracy, $65 \%$ sensitivity and $88 \%$ specificity (27). The present study using both PCa cell lines and animal prostate tumor xenograft models produced similar results in terms of enhanced radioresistance post- $\beta$-catenin nuclear translocation.

$\beta$-catenin, through its nuclear translocation, achieves transcriptional activity by binding to the transcriptional factor, LEF/TCF (29). In the study by Zhao et al, the overexpression of HIF-1 $\alpha$ stimulated the invasive potential of human PCa cells through the EMT pathway, and the Wnt/ $\beta$-catenin signaling pathway played a vital role in this process (19). This is due to the loss of epithelial features and the acquisition of mesenchymal properties through the EMT pathway leads to migration of individual cells (30). In the present study, the enhanced expression of cytoplasmic proteins over transmembrane proteins, as well as enhanced cell invasion post- $\beta$-catenin nuclear translocation were induced by HIF-1 $\alpha$ overexpression, in line with the findings of previous studies mentioned above.

Previous studies have suggested that radioresistance is a result of intrinsic adaptations; for instance, the activation of the radiation-induced DNA damage response, enhanced DNA repair capability, increased intracellular defense against ROS, and the activation of the survival pathways $(31,32)$. Cellular response to DNA damage is coordinated primarily by two signaling cascades, the ATM-Chk2 and ATR-Chk1 pathways. Following DNA damage by ionizing irradiation, Chk1/2 becomes phosphorylated by ATR/ATM and arrests cell proliferation to allow DNA repair (18). In the present study, radiation treatment led to $\beta$-catenin activation and nuclear translocation, as well as to the activation of the Chk1 and Chk2 pathways, reduced apoptotic markers and DNA fragmentation, enhanced cell proliferation, and cell cycle arrest at G0 (increased Ki67 expression) that allows sufficient DNA repair before cell division.

Based on the studies mentioned above and the current findings, a radioresistance mechanism in prostate tumors can be summarized as follows: First, the hypoxic environment in prostate tumors activates the expression of HIF-1 $\alpha$, which in turn suppresses E-cadherin expression and promotes the entry of free $\beta$-catenin into the nucleus. In addition, hypoxia induces Src kinase-dependent $\beta$-catenin phosphorylation at Y654 (33). Y654- $\beta$-catenin phosphorylation disrupts the association between $\beta$-catenin and E-cadherin, favoring its transcriptional activity (34). Once $\beta$-catenin achieves nuclear translocation, it regulates the transcription of genes involved in the EMT pathway and regulates cell cycle, DNA repair, apoptosis and cell proliferation. Subsequently, $\beta$-catenin nuclear translocation leads to radioresistance of cancer cells. In the present study, in the HIF-1 $\alpha$ overexpression group, the increased phosphorylation of GSK-3 $\beta$ at Ser9 was not reversed by $\beta$-catenin silencing, indicating that the phosphorylation of GSK-3 $\beta$ is likely regulated by hypoxia or HIF-1 $\alpha$ independent of $\beta$-catenin pathway.

In conclusion, this study firstly described a comprehensive molecular mechanism that may contribute to the development to radioresistance of PCa under HIF-1 $\alpha$ overexpression using both $\mathrm{PCa}$ cell lines and animal prostate tumor xenograft 
models. The results of our findings shed light into the selection of molecular targets for improving the radiosensitivity of prostate tumors and hence the effectiveness of radiation treatment.

\section{Acknowledgements}

Not applicable.

\section{Funding}

This study was supported by grants from the National Natural Science Foundation of China (nos. 30700968 and 81372858) and High Level Backbone Doctor Training Project of Beijing Health System (no. 2015-3-054). The funders had no role in the study design, data collection and analysis, decision to publish, or preparation of the manuscript.

\section{Availability of data and materials}

The analyzed datasets generated during the study are available from the corresponding author on reasonable request.

\section{Authors' contributions}

YLu, SPB, JZ and LL were responsible for the study design, original article drafting and editing, data acquisition and data analysis. YLu, SPB, JZhang and LL were responsible for article revision. YLu, ML, XZ, JZhao, YH, YLi, YW performed the experiments. YLu, XZ, SPB, JZhang, YJ and LL were responsible for data analysis. ML, XZ, JZhao, YH, YLi and YW were responsible for data acquisition. YLu, XZ, SPB, JZhang and LL were responsible for data interpretation and methodology. JZhang, YJ and LL were responsible for supervision. YLu, $\mathrm{XZ}$, SPB, JZhang and JZhao revised the manuscript. LL was responsible for funding acquisition and supervision. All authors have read and approved the final manuscript.

\section{Ethics approval and consent to participate}

Animal studies were conducted according to the recommendations outlined in the Guide for the Care and Use of Laboratory Animals in the Weatherall report. Animal experiments were approved by the Committee on the Ethics of Animal Experiments of the Capital Medical University, Beijing, China.

\section{Consent for publication}

Not applicable.

\section{Competing interests}

The authors declare that they have no competing interests.

\section{References}

1. Horwich A, Parker C, de Reijke T and Kataja V; ESMO Guidelines Working Group: Prostate cancer: ESMO Clinical Practice Guidelines for diagnosis, treatment and follow-up. Ann Oncol 24 (Suppl 6): vil06-vi114, 2013.

2. Chen W, Zheng R, Baade PD, Zhang S, Zeng H, Bray F, Jemal A Yu XQ and He J: Cancer statistics in China, 2015. CA Cancer J Clin 66: 115-132, 2016.
3. Mohler JL, Kantoff PW, Armstrong AJ, Bahnson RR, Cohen M, D'Amico AV, Eastham JA, Enke CA, Farrington TA, Higano CS, et al; National Comprehensive Cancer Network: Prostate cancer, version 2.2014. J Natl Compr Canc Netw 12: 686-718, 2014.

4. Zietman AL, Bae K, Slater JD, Shipley WU, Efstathiou JA, Coen JJ, Bush DA, Lunt M, Spiegel DY, Skowronski R, et al: Randomized trial comparing conventional-dose with high-dose conformal radiation therapy in early-stage adenocarcinoma of the prostate: Long-term results from proton radiation oncology group/american college of radiology 95-09. J Clin Oncol 28: 1106-1111, 2010

5. Baumann M, Krause M and Hill R: Exploring the role of cancer stem cells in radioresistance. Nat Rev Cancer 8: 545-554, 2008.

6. Johansson S, Aström L, Sandin F, Isacsson U, Montelius A and Turesson I: Hypofractionated proton boost combined with external beam radiotherapy for treatment of localized prostate cancer. Prostate Cancer 2012: 654861, 2012.

7. Khuntia D, Reddy CA, Mahadevan A, Klein EA and Kupelian PA: Recurrence-free survival rates after external-beam radiotherapy for patients with clinical T1-T3 prostate carcinoma in the prostate-specific antigen era: What should we expect? Cancer 100: 1283-1292, 2004.

8. Cooper BT and Sanfilippo NJ: Concurrent chemoradiation for high-risk prostate cancer. World J Clin Oncol 6: 35-42, 2015.

9. West CM, Davidson SE, Elyan SA, Swindell R, Roberts SA, Orton CJ, Coyle CA, Valentine H, Wilks DP, Hunter RD, et al: The intrinsic radiosensitivity of normal and tumour cells. Int $\mathbf{J}$ Radiat Biol 73: 409-413, 1998.

10. Balmukhanov SB, Yefimov ML and Kleinbock TS: Acquired radioresistance of tumour cells. Nature 216: 709-711, 1967.

11. Wei K, Kodym R and Jin C: Radioresistant cell strain of human fibrosarcoma cells obtained after long-term exposure to x-rays. Radiat Environ Biophys 37: 133-137, 1998.

12. McDermott N, Meunier A, Mooney B, Nortey G, Hernandez C, Hurley S, Lynam-Lennon N, Barsoom SH, Bowman KJ, Marples B, et al: Fractionated radiation exposure amplifies the radioresistant nature of prostate cancer cells. Sci Rep 6: 34796, 2016.

13. Brown JM and Giaccia AJ: The unique physiology of solid tumors: Opportunities (and problems) for cancer therapy. Cancer Res 58: 1408-1416, 1998.

14. Brown JM and Wilson WR: Exploiting tumour hypoxia in cancer treatment. Nat Rev Cancer 4: 437-447, 2004.

15. Harada H, Kizaka-Kondoh S, Li G, Itasaka S, Shibuya K, Inoue $M$ and Hiraoka M: Significance of HIF-1-active cells in angiogenesis and radioresistance. Oncogene 26: 7508-7516, 2007.

16. Harada $\mathrm{H}$ : Hypoxia-inducible factor 1-mediated characteristic features of cancer cells for tumor radioresistance. J Radiat Res (Tokyo) 57 (Suppl 1): i99-i105, 2016.

17. Chang HW, Nam HY, Kim HJ, Moon SY, Kim MR, Lee M, Kim GC, Kim SW and Kim SY: Effect of $\beta$-catenin silencing in overcoming radioresistance of head and neck cancer cells by antagonizing the effects of AMPK on Ku70/Ku80. Head Neck 38 (Suppl 1): E1909-E1917, 2016.

18. Cojoc M, Peitzsch C, Kurth I, Trautmann F, Kunz-Schughart LA, Telegeev GD, Stakhovsky EA, Walker JR, Simin K, Lyle S, et al: Aldehyde dehydrogenase is regulated by $\beta$-catenin/TCF and promotes radioresistance in prostate cancer progenitor cells. Cancer Res 75: 1482-1494, 2015.

19. Zhao JH, Luo Y, Jiang YG, He DL and Wu CT: Knockdown of $\beta$-catenin through shRNA cause a reversal of EMT and metastatic phenotypes induced by HIF-1 $\alpha$. Cancer Invest 29: 377-382, 2011.

20. Luo Y, Lan L, Jiang YG, Zhao JH, Li MC, Wei NB and Lin YH: Epithelial-mesenchymal transition and migration of prostate cancer stem cells is driven by cancer-associated fibroblasts in an HIF-1 $\alpha / \beta$-catenin-dependent pathway. Mol Cells 36: 138-144, 2013.

21. Wang J, Zhou D, He X, Wang Y, Hu W, Jiang L and Dou J: Effect of downregulated $\beta$-catenin on cell proliferative activity, the sensitivity to chemotherapy drug and tumorigenicity of ovarian cancer cells. Cell Mol Biol (Noisy-le-grand) 57 (Suppl): OL1606-OL1613, 2011.

22. Rahbar Saadat Y, Saeidi N, Zununi Vahed S, Barzegari A and Barar J: An update to DNA ladder assay for apoptosis detection. Bioimpacts 5: 25-28, 2015.

23. Gouazé-Andersson V, Delmas C, Taurand M, Martinez-Gala J, Evrard S, Mazoyer S, Toulas C and Cohen-Jonathan-Moyal E: FGFR1 induces glioblastoma radioresistance through the PLC $\gamma /$ Hif $1 \alpha$ pathway. Cancer Res 76: 3036-3044, 2016. 
24. Marampon F, Gravina GL, Zani BM, Popov VM, Fratticci A, Cerasani M, Di Genova D, Mancini M, Ciccarelli C, Ficorella C, et al: Hypoxia sustains glioblastoma radioresistance through ERKs/DNA-PKcs/HIF-1 $\alpha$ functional interplay. Int J Oncol 44 $2121-2131,2014$

25. Orsulic S, Huber O, Aberle H, Arnold S and Kemler R: E-cadherin binding prevents beta-catenin nuclear localization and beta-catenin/LEF-1-mediated transactivation. J Cell Sci 112: $1237-1245,1999$.

26. Zhang Y, Fan N and Yang J: Expression and clinical significance of hypoxia-inducible factor $1 \alpha$, Snail and E-cadherin in human ovarian cancer cell lines. Mol Med Rep 12: 3393-3399, 2015.

27. Wang L, Zhang XM, Li Z, Liu XJ, Chai J, Zhang GY and Cheng YF: Overexpression of nuclear $\beta$-catenin in rectal adenocarcinoma is associated with radioresistance. World J Gastroenterol 19: 6876-6882, 2013.

28. Zhang Q, Gao M, Luo G, Han X, Bao W, Cheng Y, Tian W, Yan M, Yang G and An J: Enhancement of radiation sensitivity in lung cancer cells by a novel small molecule inhibitor that targets the $\beta$-catenin/Tcf4 interaction. PLoS One 11: e0152407, 2016.

29. Nelson WJ and Nusse R: Convergence of Wnt, beta-catenin, and cadherin pathways. Science 303: 1483-1487, 2004.
30. Guarino M: Epithelial-mesenchymal transition and tumour invasion. Int J Biochem Cell Biol 39: 2153-2160, 2007.

31. Bütof R, Dubrovska A and Baumann M: Clinical perspectives of cancer stem cell research in radiation oncology. Radiother Oncol 108: 388-396, 2013.

32. Peitzsch C, Kurth I, Kunz-Schughart L, Baumann $M$ and Dubrovska A: Discovery of the cancer stem cell related determinants of radioresistance. Radiother Oncol 108: 378-387, 2013.

33. Xi Y, Wei Y, Sennino B, Ulsamer A, Kwan I, Brumwell AN, Tan K, Aghi MK, McDonald DM, Jablons DM, et al: Identification of pY654- $\beta$-catenin as a critical co-factor in hypoxia-inducible factor- $1 \alpha$ signaling and tumor responses to hypoxia. Oncogene 32: 5048-5057, 2013.

34. Roura S, Miravet S, Piedra J, García de Herreros A and Duñach M: Regulation of E-cadherin/Catenin association by tyrosine phosphorylation. J Biol Chem 274: 36734-36740, 1999.

(7)(2) This work is licensed under a Creative Commons Attribution-NonCommercial-NoDerivatives 4.0 International (CC BY-NC-ND 4.0) License. 